\title{
BILDIRI METNi
}

\section{Küre-Ersizlerdere Köy Tasarım Rehberi; Süreç ve Yöntem Üzerine Bir Tartışma'}

\author{
Küre-Ersizlerdere Village Design Guide: A Debate on Process and \\ Methodology
}

\author{
Hürriyet Öğdül,, ${ }^{1}$ Mustafa Gül, ${ }^{2}$ İnci Olgun,, ${ }^{1}$ Seher Demet Kap Yücel, ${ }^{1}$ Çare Olgun Çalışkan ${ }^{1}$ \\ ${ }^{1}$ Mimar Sinan Güzel Sanatlar Üniversitesi Şehir ve Bölge Planlama Bölümü \\ ${ }^{2}$ istanbul Kalkınma Ajansı
}

\section{ÖZ}

Türkiye'de kırsal alan sorunları planlama alanında da kendini göstermekte, ancak müdahale yöntemleri kısıtlı kalmaktadır. Organik biçimde gelişen bir sürecin sonucunda Türkiye'nin ilk köy tasarım rehberi Ersizlerdere köyü için üretilmiştir. Rehber hazırlama süreci Mimar Sinan Güzel Sanatlar Üniversitesi (MSGSÜ), Kuzey Anadolu Kalkınma Ajansı (KUZKA), Küre Kaymakamlığı gibi kırsal kalkınmada yeni yöntem arayışlarında olan aktörlerin karşılaşması ile başlamıştır. Aktörlerin ortaya koyduğu irade ile Küre'de yapılan yerel kalkınma çalıştayında önerilen birçok kilit proje içinde köy tasarım rehberi de bulunmaktadır. Bu önerilerden yola çıkarak ve Kastamonu Valiliği, KUZKA ve MSGSÜ arasında imzalanan iş birliği protokolüne dayanarak Ersizlerdere Köy Tasarım Rehberi hazırlanmıştır. Kırsal alandaki planlama çabalarında görülen düşük katılım düzeyinin artırılması hedeflenmiş ve saha çalışmalarının yaygın biçimde yapılması katılım düzeyini artırmıştır. Köyde anketler, odak grup görüşmeleri yapılarak köy halkının sürece dâhil edilmesi sağlanmış ve böylelikle birincil veri toplanmıştır. Yerleşime dair yapılan analizlerde kırsal kimlik ögelerinin tespit edilmesi hedeflenmiştir. Bu kapsamda, topoğrafya, peyzaj, silüet ve yerleşme dokusunun incelendiği mekânsal analizler, parsel yapısı-kullanımı ve mimari ölçekte rölöve ve yapı elemanlarına dair analizler yapılmıştır. Çalışma kapsamında elde edilen bulgular ve köye dair temel bilgiler ışı̆̆ında rehberin içeriği ve kurgusu belirlenmiştir. Rehber üç ana bölümden oluşmaktadır: Yerleşme Dokusu, Parsel Biçimlenişi ve Kırsal Mimari Karakter. Yerleşme Dokusu başlığında silüet, bakı, rakım, bitki ve arazi örtüsü, ortak kamusal mekânlar, yollar ve patikalar hakkında öneriler yer almıştır. Parsel Biçimlenişi başlığında yapılaşma konusu ele alınmıştır. Kırsal Mimari Karakter başlığında ise yapı/ parsel düzeni, mekân organizasyonu, malzeme ve yeni yapılar için öneriler yer almıştır. Sonuç olarak Türkiye'de köy tasarım rehberi çalışmalarının kırsal kalkınma girişimleri ile bağlantılı olması gerektiği, süreçte kurumsal sahiplenme, akademik katkı ve yerel katılımın önemi belirtilmiş, rehberin içeriğinin yerele özgü şekilde farklılaşabileceği ve bunun için Türkiye'de daha fazla örnek çalışmanın ve uygulamanın yapılması gerektiği vurgulanmıştır.

Anahtar sözcükler: Köy tasarım rehberi; kırsal planlama; Küre-Ersizlerdere.

\section{ABSTRACT}

Problems of rural areas in Turkey manifest themselves in planning field as well however means of intervention is limited. As a result of process growing organically, the first village design guide in Turkey was produced for the village of Ersizlerdere. The preparation process of the guide started when actors such as Mimar Sinan Fine Arts University, North Anatolian Development Agency (NADA) and Governorship of Küre looking for new methods in rural development encountered. With the will of the actors, village design guide became one of the key projects that were proposed in the local development workshop held in Küre. Depending upon this proposal and the agreement of cooperation between Governorship of Kastamonu, NADA and MSGSU, Ersizlerdere Village Design Guide was prepared. It was aimed to raise the low level of participation in the planning efforts in rural areas and the level of participation was raised thanks to extensive field work. Village people were included in the process through questionnaires conducted and focus group meetings held and thus primary data were collected. With the settlement analyses it was aimed to determine the elements of rural identity. In this context, spatial analyses examining topography, landscape, silhouette and settlement fabric; analyses about parcel structure and usage and architectural survey were made. In the light of findings obtained through the work and basic information about village, the content and construct of the guide were determined. The guide consists of three main chapters: Settlement Fabric, Parcel Formation and Rural Architectural Character. In the chapter of Settlement Fabric, there are proposals about silhouette, aspect, altitude, vegetation and land cover, common public spaces, roads/paths. In the chapter of Parcel Formation some proposals about parcel size and lot coverage are developed. Rural Architectural Character, there are proposals about building/parcel layout, spatial organization, materials and new buildings. Consequently, it was remarked that in Turkey village design guide studies must be interrelated with rural development initiatives and that sense of ownership of the institutions, academic contribution and local participation are important. It was emphasized that the content of the guide might differentiate according to the locality and that is why more studies and implementation are required in Turkey.

Keywords: Village design guide; rural planning; Küre-Ersizlerdere.

\footnotetext{
“Makalenin konusu olan çalışma ile ilgili yayın ve proje bilgileri şu şekildedir; ÖĞDÜL, H., OLGUN, I., ÇALIŞKAN, C.O. (eds.) (20I5). Kastamonu-Küre, Ersizlerdere Köy Tasarım Rehberi, Kuzey Anadolu Kalkınma Ajansı (KUZKA) yayını. Proje Koordinatorleri: Güzin KONUK, Mustafa GÜL; Proje Yürütücüsü: Hürriyet ÖĞDÜL; Proje Danışmanı: A Erdem ERBAŞ; Proje Ekibi: (soyadı alfabetik sırası ile) Meral ABAKLIOĞLU, Ahmetcan ALPAN, Burcu BUKEN CANTIMUR, Çare Olgun ÇALIŞKAN, Kumru ÇILGIN, Esin HASGÜL, Başak INCEKARA, Inci OLGUN, Tuğba ORMAN, Esra TURGUT, Seher Demet YÜCEL.
}

Geliş tarihi: 01.II.2017 Kabul tarihi: 21.02.2018

Online yayımlanma tarihi: 27.04.2018

İletişim: Hürriyet Öğdül.

e-posta: hurriyet.ogdul@msgsu.edu.tr
TMMOB Şehir Plancıları Odası 


\section{Giriş}

Kırsal alanlarla ilgili yaşanan değişimler yeni gündem konuları ve araştırma alanlarının ortaya çıkmasına neden olmuştur. Uluslararası ve ulusal politikaların sonucu olarak tarımsal üretim sürecindeki değişimler ve kırsal alanların yönetiminin yeniden biçimlenmesi, temelde kırsal alanlardaki sorunların çözümüne odaklanan birçok araştırma alanı için yeni konuları gündeme getirmiştir. Bu bağlamda sorgulanan konulardan biri de planlama disiplininin kırsal alandaki etkinliğidir.

Kentsel alanların sorunlarından yola çıkılarak gelişmiş olan planlama pratiğinin kırsal alandaki etkinliği birçok boyutla ilişkilidir. Kırsal alanlarda planlama araçlarının yeterli olup olmaması, karar süreçlerinde katılımın düzeyi ve yerel yönetimlerde işbirliği potansiyeli gibi farklı boyutlar ön plana çıkmaktadır. Makalede bu üç boyutun birbiri ile uyumlu olarak geliştirildiği bir çalışmanın aktarılması hedeflenmektedir. Bu kapsamda Kastamonu/Küre-Ersizlerdere Köyünde yeni bir mekânsal düzenleme aracı olan köy tasarım rehberinin, yerel katılım ve kurumlar arası iş birliği ile hazırlanma süreci ve yöntemi aktarılarak genel bir değerlendirme yapılacaktır.

Özellikle rehberin, yerel kalkınma ile kırsal planlama çalışmalarının bir parçası olması ve kurumlar arası işbirliği doğrultusunda geliştirilmesi ülkemiz için bir ilk örnek niteliğindedir. Buna ek olarak rehberin içeriği, bir ilk olması itibariyle çalışma sürecinde tartışılarak ve yerele özgü şekilde biçimlendiğinden bu yönüyle de özgünlük taşımaktadır.

Makalede ilk olarak kırsal alanlarda planlamanın temel sorunları ve eksiklikleri ele alınacaktır. Daha sonra Küre-Ersizlerdere Köy Tasarım Rehberi'nin geliştirilme süreci ayrıntıları ile aktarılacak ve çalışma alanına ilişkin genel bilgiler verilecektir. Bir sonraki bölümde, köye ilişkin temel bilgiler aktarıldıktan sonra rehberin içeriği, hazırlık yöntemi ve kurgusu anlatılacaktır. Son bölümde ise ülkemizde köy tasarım rehberlerinin hazırlanması ve uygulanması konusunda dair genel bir değerlendirme yapılacaktır.

\section{Kent Kıskacındaki Kırsal Alanlar}

Kırsal alanlar uzun bir zaman hızla gelişen kentlerin gölgesinde kalmış, ekonomik ve toplumsal anlamda gözardı edilmiştir. Dünya nüfusunun yalnızca beşte birini barındıran 600 kentsel merkez küresel hasılanın yaklaşık yüzde 60'ını üretmektedir (McKinsey Global Institute, 20I I). Kentlerin küresel ekonomideki bu baskın rolü ülkelerin kalkınma stratejilerini de şekillendirmekte ve özellikle hızlı kentleşen gelişmekte olan ülkelerde kırsal alanlara yönelik politikalar geri planda kalmaktadır. Bu durum Türkiye için de geçerlidir. İstanbul, Ankara, İzmir ve Bursa gibi metropoller Türkiye ekonomisinin büyük bölümünü oluşturmaktadır. Nüfusun kentsel alanlarda birikerek yoğunlaşması sonucu kentler nüfusun temsil alanları olarak sürekli daha fazla öne çıkmakta, temsil gücü azalan kırsalı da geri plana itmektedir. Kentlerde yoğunlaşan stratejiler, kentsel politikada farklı yaklaşımlar üretebilirken kırsal alanlarda geleneksel stratejilere dayalı politika ve araçlar kullanılmaktadır. Yakın gelecekte kırsal nüfus ve yaşam alanları üzerindeki kentleşme baskıları sonucu niceliksel ve niteliksel kayıpların süreceği ve sonuçta sağılılı (doğal) gıdaya erişim, tarım, ekoloji, kırsal yaşamın devamlılığı gibi konularda oluşacak tahribatın önüne geçilmesi gerekliliği vurgulanmaktadır. Bir yandan göç yoluyla nüfus kaybına uğrayan kırsal alanlar, farklı bir akışın da merkezinde yer almaya başlayarak, gelişen ulaşım-haberleşme imkânlarının da etkisiyle büyük kentlerde yaşamak istemeyenler için alternatif yaşam ve kimi zaman da alternatif çalışma alanları olabilmektedir.

\section{Kırsal Alanda Yaklaşımlar ve Araçlar}

Günümüzde mekânsal planlamanın, kırsal alanları doğrudan içermek ve gerekli duyarlılıkları geliştirmek durumunda olduğu yönünde bir fikir birliği oluşmaktadır. Ancak, kırsal mekâna müdahale araçlarının yetersiz olması ya da etkin kullanılamaması nedeniyle kırsal alan planlaması bakımından çözüm yaklaşımlarını eksik bırakan, boşluklu bir durum söz konusudur. Bu durum kırsal alanlara yönelik müdahalelerde yeni yaklaşımların kullanılmasını da zorunlu kılmaktadır.

Türkiye'de kırsal kalkınma stratejisi diğer tüm alanlarda olduğu gibi tavandan tabana bir yaklaşım içermektedir. 20। 4-2020 Ulusal Kırsal Kalkınma Stratejisi'nde (Gıda Tarım ve Hayvancılık Bakanlığı, 20।5, s. I0) belirtildiği gibi kırsal kalkınma, kırsal alanda yaşayan fertlerin ekonomik ve sosyal refahı ile yaşam kalitesini artırma sürecidir. Kırsal alanlarda yaşayan fertlerin yaşam kalitesini artırmak doğal olarak o fertlerin sorunlarının çözümüne kendilerinin de katılım sağlamalarını gerektirir. Türkiye'de kırsal nüfus yoğunluğunun düşük ve nüfusun daha çok yaşlı olması, yerleşmelerin genellikle dağınık olması gibi nedenler politika yapıcı ve uygulayıcılarının kırsal alana yönelik müdahalelerinde yerel halkla istişare etmeleri ve yerel halkı sürece katmaları için zorlayıcı koşullar olarak görülebilir.

Bu dezavantajlarına karşın, kırsal yerleşmelerin görece küçük ölçekli yerleşmeler olması bazı fırsatlar sunmaktadır. Ostrom (2009); metropolden küçük ölçekli yerleşimlere doğru gidildikçe işbirliği, kolektif eylem gücü yaratma ve katılımlı sonuç elde etmenin kolaylaştığını ortaya koyarken (Akt: Harvey, 2013), Wirth'se (1938) kentsel mekânın büyüdükçe bireyler arasındaki sosyalleşme altyapısını olumsuz yönde etkilediğini ve toplumsal kayıtsızlığa yol açtığını savunmaktadır (Akt: Saunders, 2013). Buna rağmen, kırsal alana yönelik müdahalelere karar verildikten sonra yerel halkın bilgisine sunulmakta ve doğal olarak bu gibi süreçler, Arnstein (1969) tarafından geliştirilen katılım merdiveninin en alt kısmında yer alan "katılımsızlık” olarak adlandırılabilmektedir. Ancak kırsal alanlarda 
katılım ve ortak iş geliştirme kapasiteleri etkin ve kararlı bir şekilde sürece katıldığında sonuç elde etmeyi kolaylaştırıcı bir durum yaratılması mümkündür. Burada katılımın sembolik anlamından uzak şekilde, sürecin başından sonuna kadar dikkate alınması, ortaya koyulacak fikir/eylem/proje vb. konuların ortak çerçevede karara bağlanmasına olanak tanımaktadır.

Kırsal alanda katılımın sağlanması günlük yaşamın geçtiği mekâna dair müdahalelerde özellikle önemlidir. Yerel yönetimlerin yaşam koşullarını iyileştirmeyi hedefleyen farklı tür müdahalelerinin olmasına karşın kırsal mekâna yönelik politika ve uygulamalarının eksik kaldığı görülmektedir. Geçmiş yıllara bakıldığında daha çok merkezi hükümet düzeyinde, kırsal kalkınma odaklı bazı girişimlerin olduğu görülmektedir. 1930'larda ideal bir köy planının ayrıntıları ile çizildiği örnek köy modeli, mekâna dair öngörüleri olan ilk yaklaşımdır. 1930'lu ve 1940'lı yıllarda eğitim yoluyla kırda modernleşmeyi hedefleyen köy enstitüleri, 1970'li yıllardan sonra köylere hizmet götürülmesi ve istihdam sağlanmasını hedefleyen merkez köy ve köy- kent gibi uygulamalar dikkat çekmektedir (Çelik, 2005; Kayıkçı, 2005; Güler, Çırakoğlu ve Tokmak, 2014; Türkoğlu, 1999; Koç ve Gül, 2006; Çetin, 1999). Bu uygulamaların mekâna etkileri dolaylı olmuştur. 1980'lerden sonra daha çok uluslararası örgütler ve $A B$ etkisiyle şekillenen kırsal politikaların ülkemizdeki uygulanış biçimlerinin yerel ekonomileri zayıflatarak gerekli yaşam koşullarını zorladığı; diğer yandan ekolojik değerler ve tarımsal alanların kaybına neden olduğu görülmektedir (Aysu, 2013). 2000'li yıllarda, etkisi daha da belirginleşen kentleşme süreçleri kent ile kır arasındaki ilişkilerin ve sınırların değiştiği ve kentsel nitelikli alan ve nüfus birikimlerinin sürekli büyüyerek yayıldığı bir dönemi ifade etmektedir. Diğer yandan da birçok köy yerleşimi alternatif/doğa/eko turizm gibi alanlarda önemli ekonomik ve mekânsal dönüşüm süreçlerine girmişlerdir. Bu süreçler kimi zaman olumlu gelişme etkileri gösterirken kimi zamansa kırsal yerleşim karakterlerinin ve özgün kimlik değerlerinin kaybına neden olmaktadır.

Ülkemizde mekâna müdahale anlamında etkin olan kurumlar içinde kırsal kalkınma, hizmet ve altyapı sağlama ile ilgili kurumlar (örn. TKDK²) ve bölgesel gelişme için strateji ve planlar üreten kurum olarak Kalkınma Ajansları doğrudan olmasa da mekânsal etkileri olan yetkilere sahiptir. 20 I2-20 I 3 yıllarında yürürlüğe giren Büyükşehir yasaları ile birlikte alanları genişleyen büyükşehir belediyeleri de kırsal alanlarda mekânsal düzenleme ve planlama konusunda geniş yetkilere sahiptir. Bu yasal düzenlemelerin ve kırsalda el değiştiren yetkilerin kırsal alanlarda yaşam kalitesini ve koşullarını nasıl etkileyeceği ilerleyen dönemlerde daha net ortaya çıkacaktır.

Yerel yönetimlerin kırsal mekânı düzenleme araçlarına bakıldığında Büyükşehir Belediyeleri için 3194 sayılı İmar Kanunu ve ilgili yönetmelikler, diğer alanlar için 442 sayılı Köy Kanunu ile afet ve iskân ile ilgili kanunlar dışında fazla bir araç olmadığını söylemek mümkündür. Bu mevzuat köylerde gelişme alanları belirleme, parselasyon, donatı alanları eklenmesi yapılaşma koşulları getirilmesi ile sınırlıdır ve yaptırıma dayalıdır. İmar Kanunu'na 2013 yilında eklenen bir madde ile yeni bir araç olarak Köy Tasarım Rehberi ise mevzuata giren ve kırsal alanları doğrudan merkezine alan en güncel ve önemli araçlardan biridir.

Ersizlerdere Köyü için hazırlanan rehber, bir yandan ülkemiz için bir köy tasarım rehberinin nasıl olması gerektiği konusunda bazı öneriler getirmekte, bir yandan da yukarıda bahsedilen yerel katılım meselesinde yaşanan bir tecrübeyi aktarmaktadır.

\section{Köy Tasarım Rehberine Doğru}

Ersizlerdere Köyü için hazırlanan köy tasarım rehberinin oluşum süreci öncesinde ilk etapta, Kastamonu'daki yerel aktörlerin; kentlerin yoğun çekiciliği karşısında güçsüzleşen kırsal alana yönelik etkin stratejinin ve müdahale yöntemlerinin ne olabileceğine ilişkin arayış içinde oldukları söylenebilir. Keza mevcut teşvikler, hibeler ile yol, kanalizasyon, baraj, içme suyu, turizm vb. yatıımları Kastamonu kırsalının gerilemesini durdurmada yeterli olamamıştır. Köy Tasarım Rehberi mevcut araçların tamamlayııısı olarak bu bağlamda ortaya çıkmakla beraber rehberin oluşturulmasında yaşanan süreç de rehberin gelişiminde doğrudan etkili olmuştur. Rehberin oluşturulması süreci 4 bileşene ayrılabilmektedir. Bunlar karşılaşma, aktör iradesi, katılımclık/dâhil olma ve kurumsallaşmadır. Bu bileşenler birbirlerinden bağımsız bir biçimde ardışık olarak gelişmemiş, tam aksine her bir bileşen birbiriyle örtüşerek bir bütünü tamamlamıştır. Süreci daha iyi anlamak için bu 4 bileşenin belirginleştirilmesi bu kapsamda önemlidir. Bu bileşenler kapsamındaki faaliyetler Tablo I ile de özetlenmiştir.

Karşılaşma süreci Mimar Sinan Güzel Sanatlar Üniversitesi (MSGSÜ) Kırsal Alan Planlaması ve Köy Yenileme lisans dersi kapsamında gerçekleştirilen saha araştırması için Küre İlçesi Ersizlerdere Köyü'nün seçilmesi ile başlamıştır. 2013 yılının Nisan ve Mayıs aylarındaki saha araştırması esnasında Küre Kaymakamlığı, Küre Belediyesi, Ersizlerdere Muhtarlığı, köydeki ilgili aktörler (dernek, kooperatif, köy halkı ve özellikle köylü kadınlar vb.) ile Kuzey Anadolu Kalkınma Ajansı (KUZ$\mathrm{KA}$ ) arasında etkileşim başlamıştır. Bu karşılaşma ve etkileşim sayesinde yerel aktörler köy tasarım rehberi ve kırsal planlama yaklaşımı hakkında bilgi sahibi olmuş ve zaten yeni yaklaşımlar içerisinde olan Kastamonu Valiliği, Küre Kaymakamlığı ve Kuzey Anadolu Kalkınma Ajansı bu yeni yaklaşımın Ersizlerdere Köyü ve Kastamonu için sergilediği potansiyeli fark etmişlerdir. MSGSÜ'nün kırsal planlama konusundaki bilgi birikimi ile yerel aktörlerin kırsal sorunları çözecek yeni yöntemler arayışının çakışması sürecin dinamiğini oluşturmuştur.

Bir karşılaşma ile başlayan süreç, aktörlerin bu potansiyeli fark

\footnotetext{
2 TKDK: Tarım ve Kırsal Kalkınmayı Destekleme Kurumu
} 
Tablo I. Ersizlerdere köy tasarım rehberin oluşum süreci

\begin{tabular}{|c|c|c|c|}
\hline Bileşeni & Yil & Ay & Kilit Faaliyet \\
\hline \multirow[t]{2}{*}{ Karşılaşma } & \multirow[t]{4}{*}{2013} & Nisan & $\begin{array}{l}\text { MSGSÜ Kırsal Alan Planlaması ve Köy Yenileme Dersi kapsamında saha } \\
\text { ziyareti ve çalışması }\end{array}$ \\
\hline & & Mayıs & $\begin{array}{l}\text { Kırsal Alan Planlama ve Köy Yenileme Dersi kapsamında gerçekleştirilen } \\
\text { çalışmaların Kastamonu'da sunulması }\end{array}$ \\
\hline \multirow[t]{2}{*}{ Aktör İradesi ve Katılımcılık/Dâhil Olma } & & Haziran & Geleceğe Küresel Bakış: Kırsal Kalkınma Yerel Stratejiler I. Çalıştayı \\
\hline & & $\begin{array}{l}\text { Temmuz } \\
\text { Kasım }\end{array}$ & MSGSÜ, Küre Kaymakamlığı ve KUZKA arasında gerçekleşen toplantılar \\
\hline \multirow[t]{2}{*}{ Aktör İradesi ve Kurumsallaşma } & \multirow[t]{2}{*}{2014} & Ocak & $\begin{array}{l}\text { Kastamonu Valiliği, MSGSÜ ve KUZKA arasında işbirliği protokolünün } \\
\text { imzalanması }\end{array}$ \\
\hline & & $\begin{array}{l}\text { Şubat } \\
\text { Mart }\end{array}$ & MSGSÜ, Küre Kaymakamlığı ve KUZKA arasında yapılan toplantılar \\
\hline \multirow[t]{4}{*}{ Katılımcılık/Dâhil Olma } & & Nisan & Köy Tasarım Rehberinin ve saha çalışmalarının başlaması \\
\hline & & Ağustos & Köy Tasarım Rehberi saha çalışmalarının devamı \\
\hline & & Eylül & MSGSÜ, Küre Kaymakamlığı ve KUZKA arasında yapılan toplantılar \\
\hline & & Ekim & Geleceğe Küresel Bakış: Kırsal Kalkınma Yerel Stratejiler 2. Çalıştayı \\
\hline \multirow{2}{*}{$\begin{array}{l}\text { Kurumsallaşma ve } \\
\text { Katılımcılık/Dâhil OIma }\end{array}$} & 2015 & Mart & Köy Tasarım Rehberi’nin yayınlanması ve dağıtılması \\
\hline & 2017 & Mayıs & Prototip projenin Kastamonu Ahşap Fuar'ında sergilenmesi \\
\hline
\end{tabular}

ettikten sonra gösterdiği irade ile ivme kazanmıştır. Köy tasarım rehberinin oluşmasına yönelik adımlar Kastamonu Valiliği, Küre Kaymakamlı̆̆ı, KUZKA ve MSGSÜ tarafından planlanmış ve organik biçimde başlayan süreç sistematik bir şekilde devam etmiştir. Aktörlerin iradesi ve yerel paydaşların katılımı ile olgunlaşan süreç içerisinde yerel bir inisiyatif ortaya çıkmıştır. Sürecin başlangıç aylarında MSGSÜ, Küre Kaymakamlığı ve KUZKA arasında yapılan toplantılarda özellikle tüm tarafları inisiyatife dâhil etmeyi amaçlayan katılım sürecinin nasıl yönetileceğine yönelik konular ele alınmıştır. Bu minvalde, 2013 yıIının Haziran ayında ise katılımı artırmak ve ilgili tüm aktörleri dâhil etmek için Geleceğe Küresel Bakış Kırsal Kalkınmada Yerel Stratejiler I. Çalıştayı gerçekleştirilmiştir. ${ }^{3}$ Çalıştaya yerel kurum temsilcileri, yerel halk ile ulusal ve bölgesel düzeydeki paydaşlar katılım sağlamıştır. Çalıştayda Küre'ye yönelik ana sorunların ve kilit projelerin üretildiği ve belirlendiği, "Doğal Tarım ve Ekoturizm”, “Kırsal Peyzaj ve Ekoturizm”, “Küre’de Yaşam Kalitesi ve Sanayi Mirası”, “Kültürel Miras, Tarihi Yapı ve Turizm” ile "Kırsal Kalkınmada Yerel Girişimcilik" olmak üzere 5 farklı çalışma grubu oluşturulmuştur. Çalıştayın sonunda ise Kırsal Peyzaj ve Ekoturizm grubu köy tasarım rehberlerinin oluşturulmasını kilit proje olarak önermiştir.

Çalıştay ile tetiklenen süreç aktörler arasındaki toplantılar ile devam etmiş 2014 yılının Ocak ayında Kastamonu Valiliği,
MSGSÜ ve KUZKA arasında iş birliği protokolü imzalanmış ve inisiyatif kurumsallaşmaya başlamıştır. Bu kapsamda ilk olarak 2014 yılının Mayıs ayında Küre'deki bakır madeninin sahip olduğu endüstriyel mirası konu alan "Küre: Endüstriyel Miras ve Yerel Kalkınma Uluslararası Sempozyumu” düzenlenmiş ve inisiyatifin uluslararası boyutu da güçlenmiştir. Sempozyum sayesinde ilgili tüm taraflar uluslararası deneyimleri öğrenme ve kıyaslama yapma fırsatı yakalamışlardır. Daha sonra MSGSÜ ise iş birliği protokolüne ve çalıştayda belirlenen kilit projeye istinaden Ersizlerdere Köy Tasarım Rehberi çalışmalarına başlanmıştır. Bu yeni gelişmelerin nasıl yönlendirileceğine karar vermek ve yeni aktörleri sürece katmak için, rehber çalışmalarının sona yaklaşmasıyla birlikte 2014 yılının Ekim ayında Geleceğe Küresel Bakış Kırsal Kalkınmada Yerel Stratejiler 2. Çalıştayı gerçekleştirilmiştir. ${ }^{4} 2$. Çalıştayda katılım daha genişlemiş ve I. Çalıştaydan itibaren yapılan çalışmalar aktarılmış, kilit projeler ayrıntılandırılmış, köy tasarım rehberi ile birlikte yerel kalkınmaya katkı sağlayacak yöresel ürünler ve el sanatları gibi yeni projeler de başlatılmıştır. Yerel ekonomik kalkınma için tasarımın etkin kullanılması gerekliliğine dair yaklaşımların (Ünsal, 20I2) beninmsenmesiyle yerele özgü marka yaratılmaya çalışılmıştır. Küre Kaymakamlığı'nın yerelde etkin çalışması ile Küre İlçesi'ne ait Küreden (Doğal ürünler) ve Küresel Sanatlar (Küre Kilimi, taş baskı, ahşap) gibi markaların oluşması ve kadın girişimciliğini artıracak atölyelerinin kurulması hem

3 Yücel, S.D., Kazancı, Ş. (eds.) 20।4, Geleceğe Küresel Bakış, Kırsal Kalkınmada Yerel Stratejiler Kitabı, Kuzey Anadolu Kalkınma Ajansı Yayını, Kastamonu.

${ }^{4}$ Kazancı, Ş., Aydınlı, G., Şimşek, C. (eds.) (20।6). Geleceğe Küresel Bakış, Kırsal Kalkınmada Yerel Stratejiler Kitabı-2, Kuzey Anadolu Kalkınma Ajansı Yayını, Kastamonu. 
Küre merkezde hem de Ersizlerdere Köyü’nde sürdürülebilir gelişmeyi tetikleyici bir etki yaratmıştır.

Ersizlerdere Köy Tasarım Rehberi, karşılaşmaların, etkileşimlerin, stratejinin, iradenin, motivasyonun bileşiminden oluşan bir sürecin ürünü olarak ortaya çıkmıştır. Rehberin hazırlama süreci aynı zamanda Küre'deki yerel kalkınma inisiyatifinin de bir parçası olmuştur. Yöresel sanatlar, doğal ürünler ve sokak sağlıklaştırma gibi alanlarda yapılan çalışmalarla eş zamanlı ilerlemiş ancak yerel kalkınma inisiyatifinin simgesi ve motivasyon kaynağı olmuştur. Mevzuatta yer alan planlama yöntemlerinin dışında kendisine alan yaratan ve Ersizlerdere Köyü merkezli başlayan bir inisiyatif olarak köy tasarım rehberi oluşturma süreci yerel, bölgesel, ulusal ve uluslararası ölçekte iş birliğini tetiklemiştir. Böylelikle Türkiye'nin ilk köy tasarım rehberi yöntemsel olarak da bir ilki gerçekleştirmiştir. Hem bir yerel kalkınma inisiyatifini tetikleyen bir etken hem de katılımcılığı esas alan öncü bir kırsal planlama müdahalesi olarak örnek özellikler sergilemektedir.

Süreç geneli itibarıla olumlu bir seyir izlemekle birlikte bazı alanlarda sorunlar da meydana gelmiştir. Rehberin geliştirilmesinde izlenilecek yolun belirsizliği ve ülkemiz için ilk örnek olması proje sürecinde karşılaşılan en önemli zorluk olmuştur. İmar Kanunu'nda 2013 yılında yapılan değişiklik ile “yerleşme ve yapılaşma özellikleri, mimari doku ve karakteri, gelişme düzey ve potansiyeli açısından önem arz eden köylerde bu özellikleri korumak, geliştirmek ve yaşatmak amacıyla muhtarlık katılımı ile ilgili idarelerce köy tasarım rehberleri hazırlanabilir." hükmü getirilmiş ise de hazırlama sürecine ilişkin yönlendirme yapan herhangi bir mevzuat bulunmamaktadır. Bu bağlamda Ersizlerdere Köy Tasarım Rehberi gerek içerik ve gerekse yönetişim modeli ile örnek olabilecek nitelikler taşımaktadır. Ayrıca Rehberin hazırlanması için 8 ay gibi kısa bir süre tanınmasının ve rehberin basılması ve uygulanmasında yaşanan gecikmeler de sürecin olumsuz yönleri olarak ön plana çıkmaktadır.

\section{Küre İlçesi Ersizlerdere Köyü}

Kuruluşu 13. yüzyıla kadar uzanan Ersizlerdere Köyü, Kastamonu ilinin Küre ilçesine bağlı ve 5 mahalleden oluşan bir köy

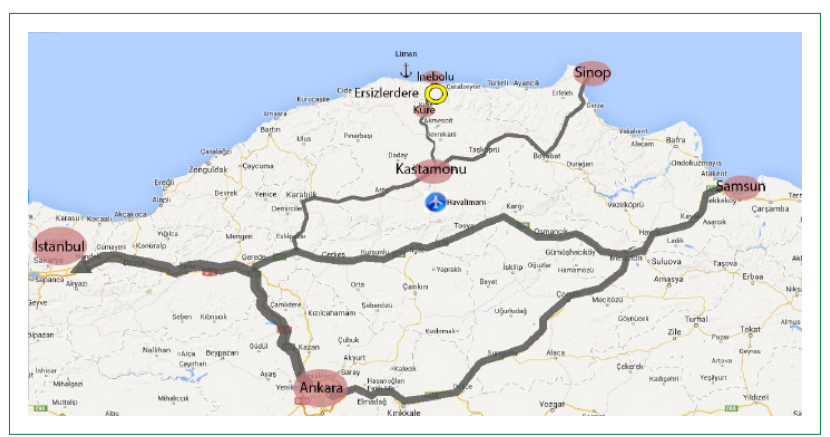

Şekil I. Küre ve Ersizlerdere'nin bölgesel ulaşım bağlantıları. yerleşimidir (Şekil I, 2). İlçede kısa mesafelerde bile değişebilen topoğrafik koşulların etkisi ile köy yerleşmelerinin büyük çoğunluğu parçalı bir dağılım göstermekte ve Ersizlerdere Köyü, bu durumun somut izlerini taşımaktadır (İbret, 2007). İlçede 750-1000 metre rakım aralı̆̆ındaki dokuz köyden biri olan Ersizlerdere, Küre dağlarının etkisi ile bol yağış alan bir bölgede ve geniş orman alanları arasında yer alır. Bölgedeki orman varlığı, köyün yerel ekonomisinde ve mimarisinde de kendini göstermektedir.

Tarımsal üretim ve hayvancılık sahası oldukça sınırlı olan köy Küre'ye 8 km, Kastamonu il merkezine 63 km uzaklıktadır. Ulaşım açısından son derece elverişli olan köyün Ersizlerdere kanyonunun giderek daha çok tanınması ile birlikte turizm değeri artmıştır. Köyün en önemli özelliklerinden biri olan ve her yönden algılanabilen kırsal peyzajı köyün içinden geçen dere ve kanyon boyunca kesintisiz devam etmektedir. 1980'li yıllardan bu yana sürekli dış göç nedeniyle nüfus kaybına (son 40 yılda köy toplam nüfusu yaklaşık \%49 oranında azalmıştır) uğrayan köyde, yapılan saha çalışmalarına göre yaklaşık 270 kişi, İlçe Nüfus Müdürlüğü verilerine göre ise 254 kişi yaşamaktadır. Ortalama hanehalkı büyüklüğü 3.8 olan köy nüfusunun \%97'si köyün yerlisi ve köydeki ortalama yaş ise 52'dir. Köy son yıllarda artan bir turizm hareketliliği içinde yer alırken yerel mimari ve geleneksel köy yaşamının son dönemde bozulmaya ve dönüşmeye başladığı da görülmektedir. Ortak kullanım mekânlarının kadınlar ve çocukların ihtiyaçlarını yeterince karşılayamadığı köy yerleşiminde, ortak-kamusal mekan gereksiniminden de söz edilebilir.

\section{Köy Tasarım Rehberi: Yöntem ve Kurgu}

Köy tasarım rehberi kırsal karakteri oluşturan ögelerin nasıl devam edeceği hakkında tavsiyeler içeren bir dokümandır. Rehber, köyde doğal çevre ile bütünlüğün nasıl korunacağı, ortak yaşam mekânlarının nasıl düzenleneceği, parsellerin iklim ve arazi koşullarına göre nasıl doğru şekilde kullanılacağı, yerel malzemelerin nasıl yeniden kullanılır hale geleceği, pencere,

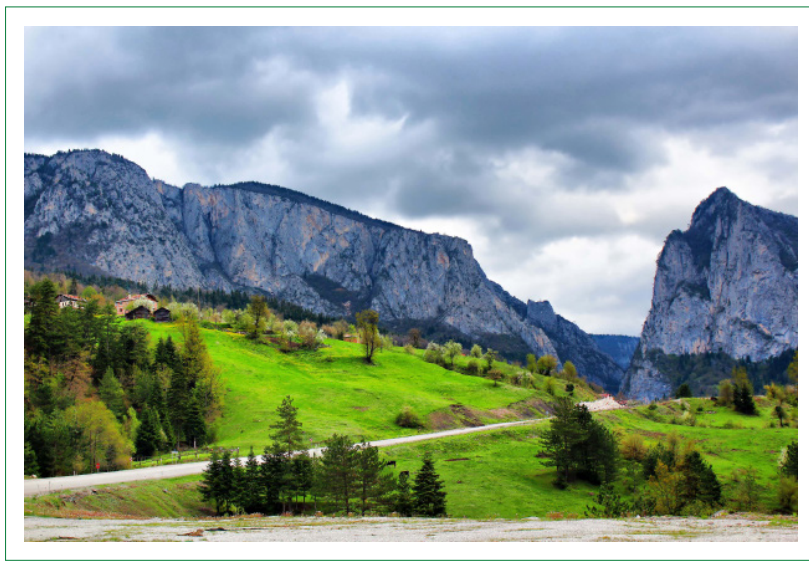

Şekil 2. Ersizlerde kanyonu. 
çatı gibi elemanların köye uyum sağlayacak şekilde nası biçimleneceği gibi ayrıntılı mekânsal konuları içerir.

Rehberin uygulandığı ülkelerde rehberin hazırlanmasında yerel topluluğun etkin bir rolü görülmektedir. Halk tarafından benimsenen bir rehberin başarı şansının yüksek olduğu kabul edilir (Owen, 1998; Owen, 2002). Ersizlerdere Köy Tasarım Rehberi hazırlık sürecinde kurgu, içerik ve yöntemin oluşturulma aşamaları tartışmalarla biçimlenmiştir. Çalışmalara başlarken ilk olarak bu konuda uygulama tecrübesine sahip olan İngiltere ve İrlanda'da rehberlerin ortaya çıkma nedenleri, içerikleri, planlama ile ilişkisi, halkın katılım biçimleri, kurumların rolü, uygulanma süreçleri incelenmiştir. Ülkelere göre rehberlerde yaklaşım ve içeriklerin nasıl değiştiği ve köy tasarım rehberleri ile ilgili temel tartışma konuları araştırılmıştır (Clifford ve King, 1993; Owen, Bishop ve O'keeffe, 20I I; Atkins, 1998; Owen, 1998; Owen, 1999; Owen, 2002; Countryside Agency, 2002; Hughes, 2006; Gallent, Morphet, Tewdyr-Jones, 2009; Owen vd., 2008).

Köy tasarım rehberi uygulama tecrübesine sahip olan İngiltere ve İrlanda'ya ait köy tasarım rehberleri (Cork County Council, 2003;Hampshire Country Council, 2009; Kilkenny County Council, 2009; Melton Borough Council, 2007; Rutland County Council, 2002; Quality Parish Council, 2014) incelenmiştir. Rehberlerin ülkelere göre farklı içerikte oldukları görülmüştür. ${ }^{5}$ Bazıları, sadece köyde parseli üzerinde ev yapmak isteyenler için hazırlanmış; parselde konum, yönlenme, bahçe düzenleme, ev planının oluşturulması gibi konuları içermektedir. Bazı rehberler yerleşme ölçeğinde hazırlanmıştır. Bu rehberler, kırsal karakterin korunması için vurgulanması gereken akslar, merkezler, köye özgü mimari ögeler, peyzaj değerleri ve yapılar gibi kimlik ögelerini belirleyerek her biri için neler yapılması gerektiğini ifade etmektedir. Katılım biçimleri de farklılık göstermektedir. Köy halkı tarafından hazırlanan, her konuya dair kısa önerilerin anket ve toplantılar yapılarak geliştirildiği örneklerin (İngiltere) yanı sıra, köy halkının katılımı ile uzmanlarca hazırlanan ve tümü aynı içerikte olan rehberler de vardır (İrlanda). Tüm örneklerde köy tasarım rehberlerinin yerel yönetimler için etkin uygulama araçları olduğu görülmüştür. Planlama sistemi içine tanımlı bir yerleri vardır. Planın eki niteliğinde, ruhsat sürecinde kullanılan belgelerdir. Rehberler sosyal ve ekonomik sorunlara dair diğer araçlarla desteklenir. Ersizlerdere Köyü için bir rehber hazırlarken ülkemizin planlama sistemi içinde köy tasarım rehberinin rolünün ne olabileceği ve içeriğinin nasıl farklılaşabileceği konuları üzerinde durulmuştur. Köy tasarım rehberi büyük oranda mekâna dayalı olsa da bir imar planı ya da imar yönetmeliği gibi algılanmamalıdır. İlgili kanununda köy tasarım rehberlerinin içerik ve yöntemine dair belirgin bir çerçeve çizilmemiş olması nedeniyle ülkemiz için ilk olacak olan Ersizlerdere Köy Tasarım rehberi, dikkatli bir süreç içinde ele alınmıştır.
Bu kapsamda Ersizlerdere Köy Tasarım Rehberi çalışması sırasında, ülkemizde kırsal yerleşmelerin planlanmasıyla ilgili kısıtlı birikim ve mevzuat dikkate alınmış, diğer ülkelerin rehberlerinde olmayan bazı içeriklerin eklenmesi hakkında tartışmalar yapılmıştır. Yerleşme ölçeğinde daha çok başlık olması gerektiğine karar verilmiştir. Nedeni yerleşme ölçeğinde korumayı sağlayacak başka araçların olmamasıdır. Rehberin plan yerine geçecek bir araç olarak görülmemesi, ancak bazı konularda -doğal sınırların korunması gibi- plan benzeri sınırlamalar da getirebileceği noktasına ekip içinde tartışmalar sonucu varılmıştır.

Ortak mekânlara özellikle önem verilmiştir. Canlılığını kaydeden köy için arazi koşullarının da etkisi ile az olan bir araya gelme imkânlarını artıracak mekânsal öneriler geliştirilmiştir. Ersizlerdere Köy Tasarım Rehberi'nin özgün yanlarından biri de mimari ölçekte güçlü bir kırsal karakter analizine dayalı olmasıdır. Restorasyon uzmanlarının desteği ile köy halkı için giderek değer kaybeden ahşap yapıların onarımı, ısı ve su yalıtımı için önerler getirilmiştir. Bunun yanı sıra kırsal mimari karaktere uygun yeni tasarımlara imkân verecek esneklik de sağlanmıştır.

Rehber temelde, köyün açık ve kapalı mekânlarında yaşam koşullarının iyileştirilmesini ve aynı zamanda kırsal mekânsal kimliğin devam etmesine yönelik çözüm ve öneriler geliştirmektedir. Yerel yönetimler için de yapı ruhsatlarında, meydan, yol ve ortak alanlarda yapılacak mekânsal düzenlemelerde yol göstericidir. Bu nedenle köy tasarım rehberinde hem yerleşme ve parsel ölçeğinde hem de mimari ölçekte analiz, ilke ve öneriler geliştirilmiştir.

Rehberin hazırlanması kararına kadar yaşanan tüm süreçlerden elde edilen bilgiler ışığında çalışma alanının özellikleri dikkate alınarak rehberin kurgusu oluşturulmuştur. Çalışma temelde masa başı ve saha olmak üzere iki alanda yürütülmüş olup, saha çalışması öncesi masa başı çalışmasında farklı uzmanlık alanlarına sahip plancı, peyzaj mimarı ve mimarlardan oluşan karma disiplinli bir ekip tarafından ülkemiz planlama koşulları çerçevesinde rehberin kurgusu tartışılmış, saha için yöntem ve teknikler belirlenmiştir. Daha sonra 2017 yılının Nisan ve Ağustos aylarında saha çalışması yapılmıştır.

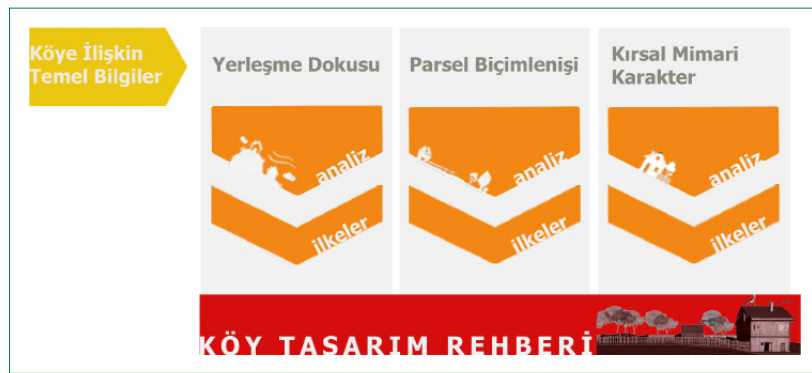

Şekil 3. Köy Tasarım Rehberi içeriği.

\footnotetext{
5 İrlanda'da Rural Design Guides (Köy Tasarım Rehberi) olarak, İngiltere'de Village Design Statement (Köy Tasarım Raporu) olarak kullanılmaktadır.
} 


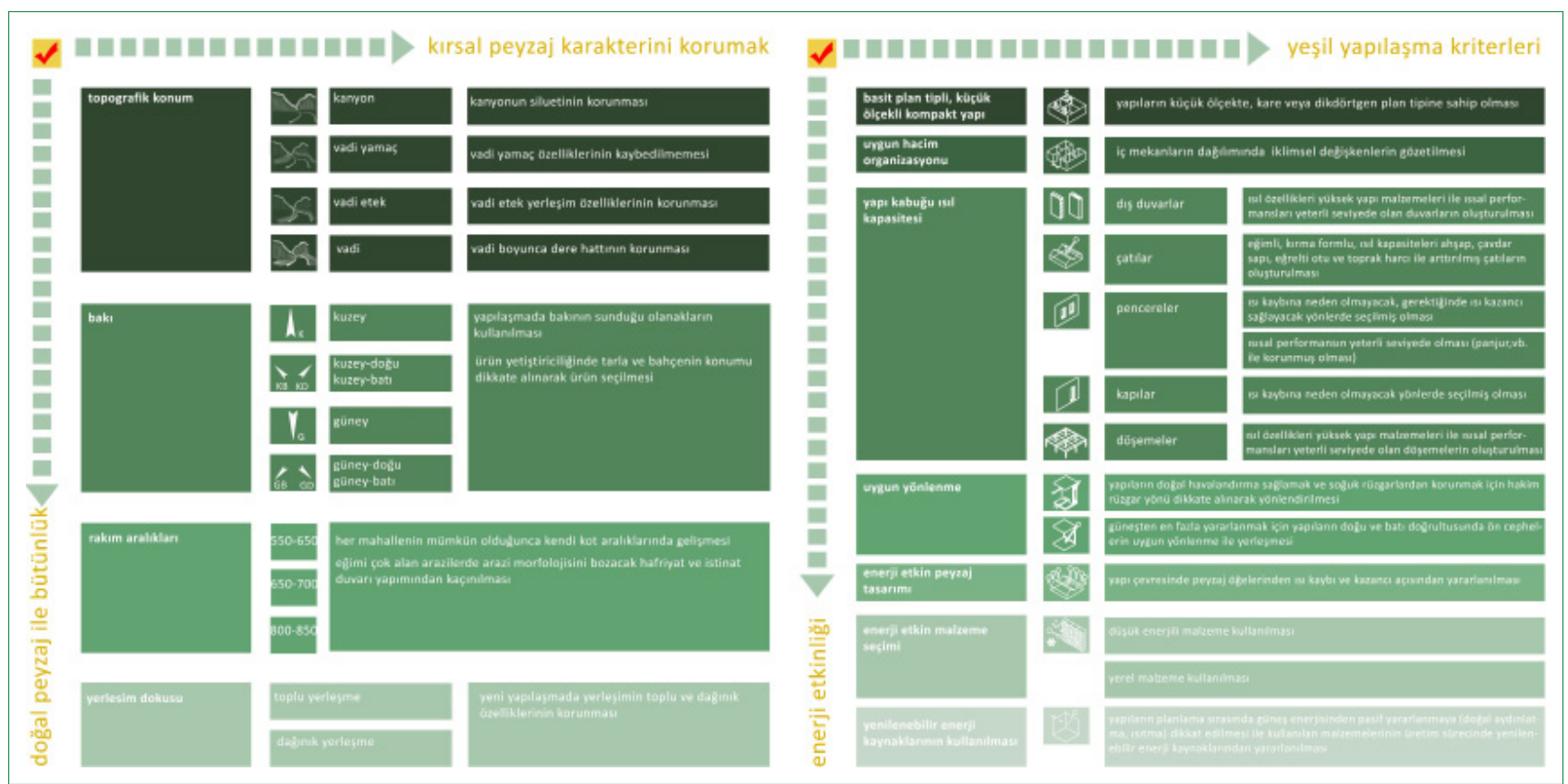

Şekil 4. Köy Tasarım Rehberi ilke örnekleri.

Ersizlerdere Köy Tasarım Rehberi üç düzeyi içerecek şekilde kurgulanmıştır: Yerleşme dokusu, parsel biçimlenişi, kırsal mimari karakter (Şekil 3). Her düzey için analizler, ilkeler ve öneriler geliştirilmiştir (Şekil 4). Analizler köyde yapılan saha çalışmalarına dayanmaktadır. İlkeler köyde oluşan fikirler ve farklı uzmanlık alanlarından ekip üyelerinin görüşleri ile geliştirilmiştir, genel ve kavramsaldır. Daha sonra Ersizlerdere Köyü için önerilerin olduğu rehber kısmı gelmektedir. Özellikle yöre halkının sürece ve rehbere katkısının sağlanması çalışmanın temel hedeflerinden biri olmuştur.

Bu kapsamda saha çalışmasında 3 farklı yöntem kullanılmıştır. Bunlardan ilki köy hakkında genel bilgileri sağlamaya yönelik hanehalkı anketleridir. Anketlerde hanehalkı profili, göç, istihdam, tarımsal üretim, bahçe kullanımı, çevreyle olan ilişki, konut yaşam alanları, köy ve konut memnuniyeti, ekoturizm, ulaşım gibi mekânsal yönü ağır basan konular yanında köydeki örgütlülük ve yardımlaşma biçimleri ile mahalleler arasındaki

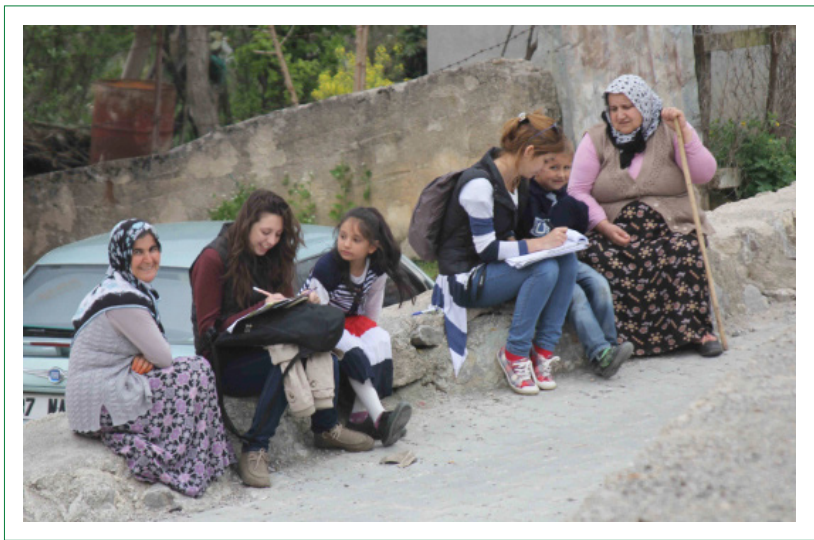

Şekil 5. Saha anket çalı̧maları. ilişkilere dair çeşitli sorular sorulmuştur. Yapılan saha çalışmasında toplam 29 hane ile görüşme yapılarak II0 kişinin demografik bilgileri elde edilmiştir (Şekil 5).

Yapılan hanehalkı anketlerine ek olarak köy içinde odak grup görüşmeleri yapılmıştır. Kadın ve erkeklerle ayrı olarak yapılan bu görüşmelerde, köye dair sorunlar ve beklentiler hakkında konuşulmuş, köyün genel sorunlarına değinilmiştir (Şekil 6). Kadınlarla yapılan odak grup görüşmesinde özellikle köye bakışları ve evleriyle ilgili düşünceleri üzerinde durulmuştur. Sahada yapılan bir diğer çalışma ise zaman-mekân çizelgesidir. Köydeki günlük yaşam ritüelini ve ortak mekânların nasıl, ne zaman ve kim tarafından kullanıldığını anlamaya yönelik gerçekleştirilen bu çizelge; köy halkının yaş, cinsiyet ve yaşanılan mahalleye göre günlük faaliyetlerini hangi mekânlarda geçirdiğini ve nasıl farklılaştığını ortaya koymaktadır.

Yerleşime dair yapılan çalışmalarda özellikle kırsal mekânı oluşturan kimlik ögelerinin tespit edilmesi hedeflenmiştir. Bu kapsamda üç farklı çalışma yapılmıştır. Bu çalışmalardan ilki

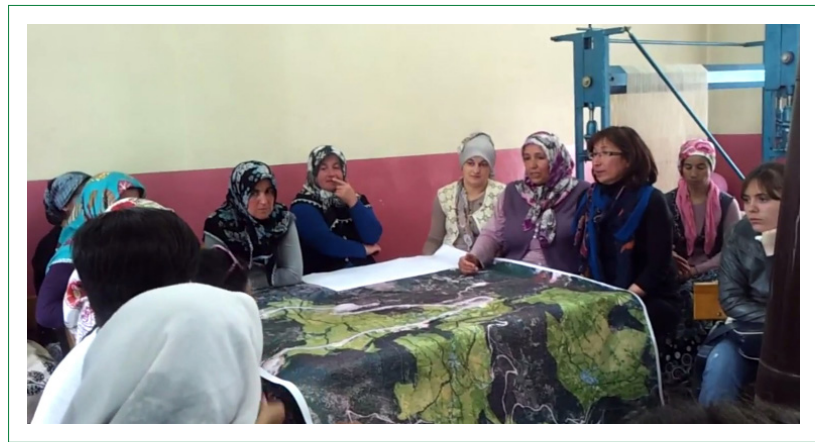

Şekil 6. Kadınlarla yapılan odak grup görüşmesi (Ağustos,20l4). 

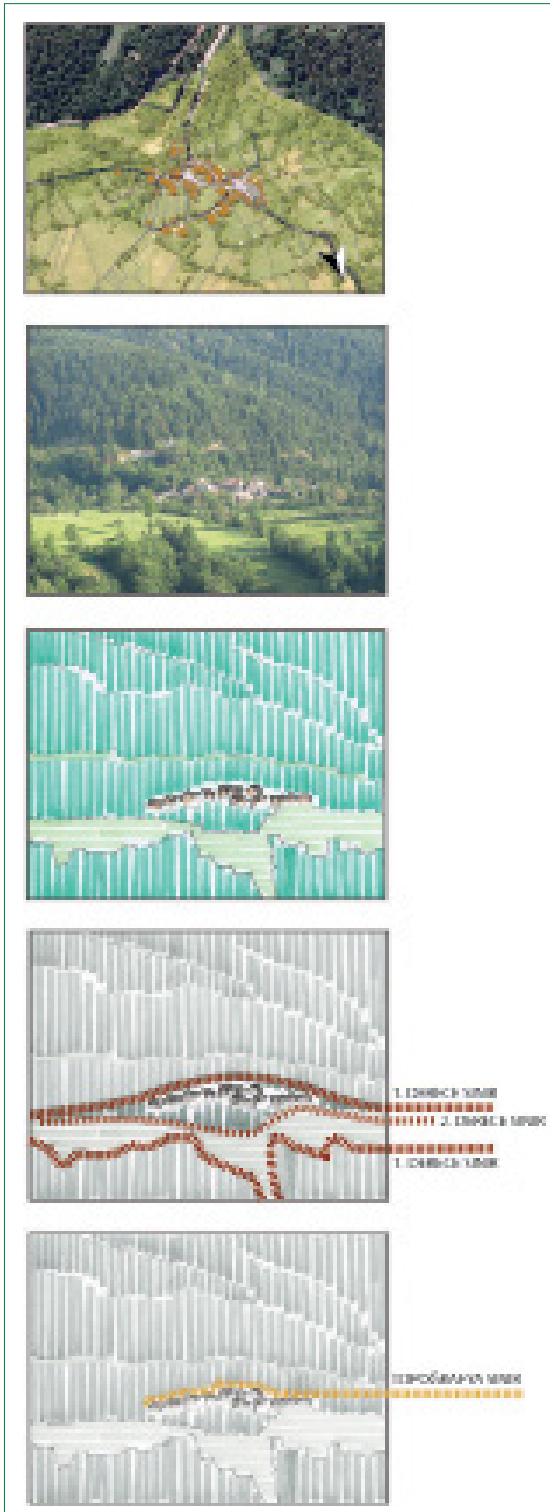
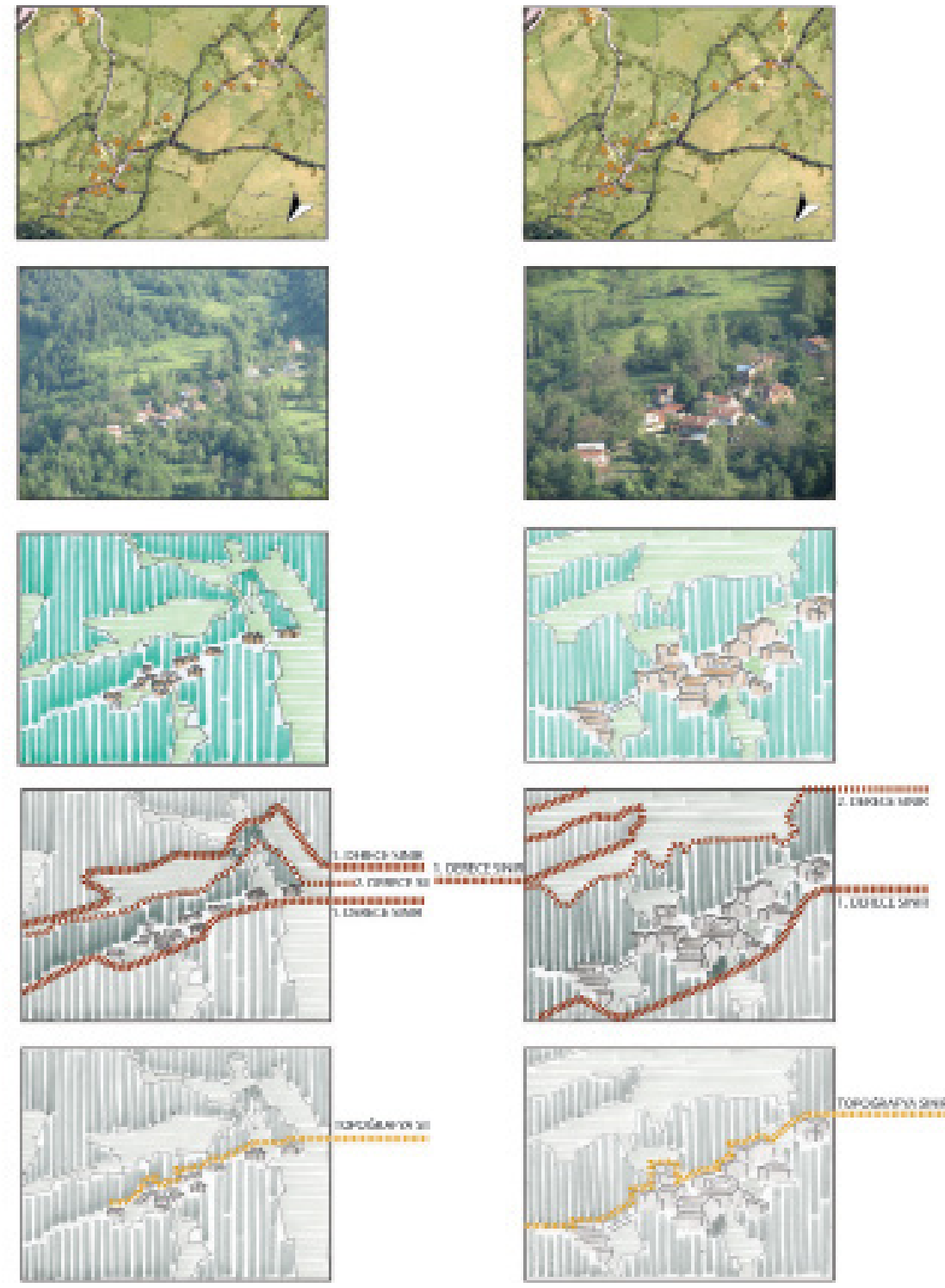
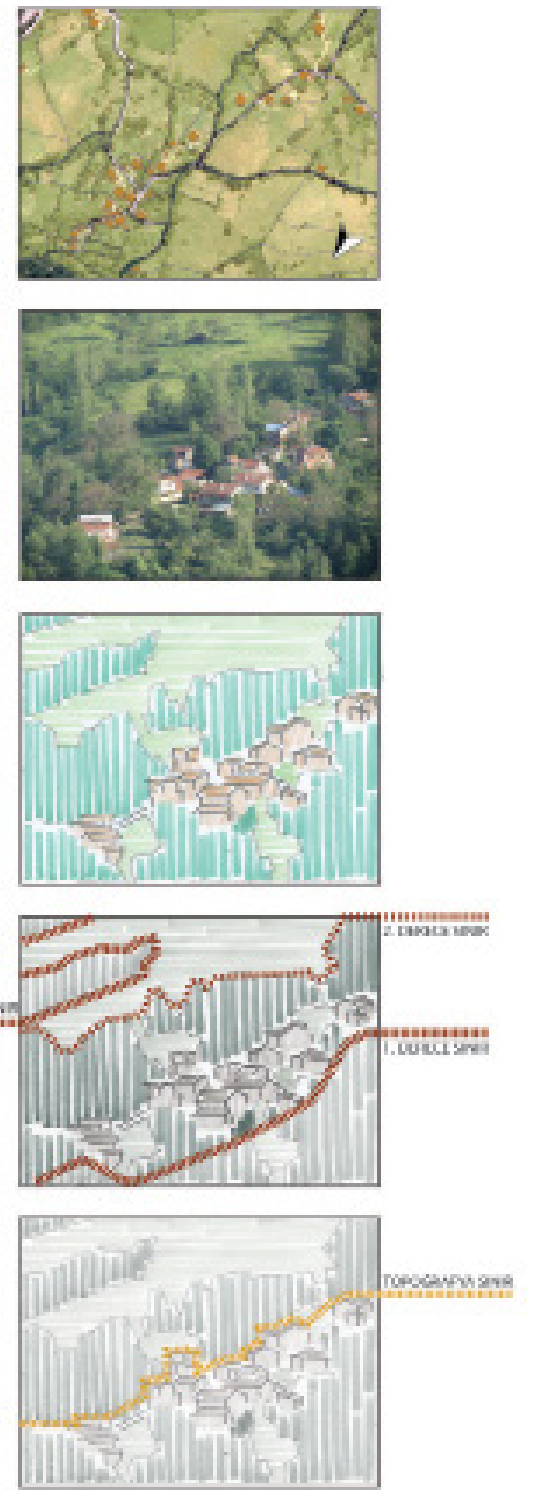

Şekil 7. Siluet açısından yerleşmede sınırlayıcı ögeler (Eminağaoğlu, 2004 çalışmasından yararlanılmıştır).

mekânsal analizlerdir. Bu çalışmada köy ölçeğinde, topoğrafya, peyzaj, siluet, yerleşme dokusu incelenmiştir (Şekil 7, 8, 9). Özellikle mahalleleri birbirine bağlayan yollar ve patikalar köylülerin de katılımıyla yürünerek gözlemlenmiş, gerekli notlar alınmış, fotoğraflar çekilerek haritaya işlenmiştir.

Bir diğer çalışma ise parsel yapısı ve kullanımına ilişkin bilgilerin sahada ayrıntılı olarak toplandığı çalışmadır. Tüm çalışma alanı içindeki mahalleleri kapsayan parseller için toplam 258 adet parsel föyü hazırlanmıştır (Şekil 10). Bu föylerde parsellerdeki yapı türleri (konut, ahır, depo vb.), kat sayıları, malzeme ve yapı kalitesi, parseldeki peyzaj elemanları (meyve ağaçları vb.), diğer ögeler (fırın, arı kovanı, çardak vb.) işlenmiş ve parsele ve yapıya dair fotoğraflar çekilmiştir. Sahada elde edilen tüm sayısal ve sözel veriler daha sonra ArcGIS programında oluşturulan veri tabanına aktarılmıştır.
Yerleşim ölçeğinde yapılan üçüncü analiz ise yapı ölçeğinde gerçekleştirilmiştir. Köyde geleneksel malzeme kullanılarak yapılan yapı stokunun zamanla betonlaşmaya başladığı ve doku-çevre uyumu gözetilmeyen malzeme-işçilik kullanılarak de-

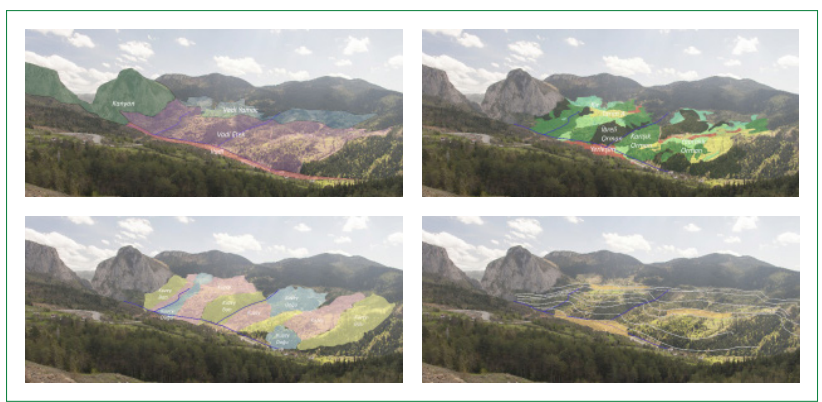

Şekil 8. Köyün peyzaj özellikleri. 




Şekil 9. Yerleşme özellikleri; kat adedi, kullanım durumu, taşıyıcı türü ve yapı kalitesi.

ğişime uğradığı tespit edilmiş ve bu çerçevede yakın geleceğe dair yönlendirmelere temel olacak ayrıntılı mimari analizler yapılmıştır (Şekil II). Çalışma alanı içindeki yapıların mimari özelliklerini belirlemek üzere 15 adet konut, 4 adet firın, 2 adet samanlık ve I adet değirmene ait rölöveler çıkarılmıştır. Kırsal mimari karakterle ilgili olarak yapı ve çevre ilişkisine dayalı analizler yapılmışır. Bu kapsamda özellikle köy yerleşiminin mimari dokusunu ve özgün kimliğini temsil eden, görece sürdüren konut kullanımları ile bunların bahçelerindeki ek yapıların fotoğraflanması, mimari kimlik bilgilerinin çıkarılması, yapı biçim ve malzeme özelliklerinin belirlenmesi sağlanmıştır. Tüm bu tespitler, yöre iklim ve topoğrafyası ile geleneksel köy yaşam kültürü içinde birbirleriyle olan ilişkileri de dikkate alınarak bütüncül olarak değerlendirilmiştir. Köyde yapılaşma süreçlerinin zaman içerisinde kullanılan malzeme türü, yapıların tipolojileri, açık-kapalı mekân kullanımları, küçük ölçekli onarım ve tadilatlar vb. konularda nasıl bir değişim yaşandığı ve nihayetinde köydeki özgün doku ve yapı biçimlerinin ne

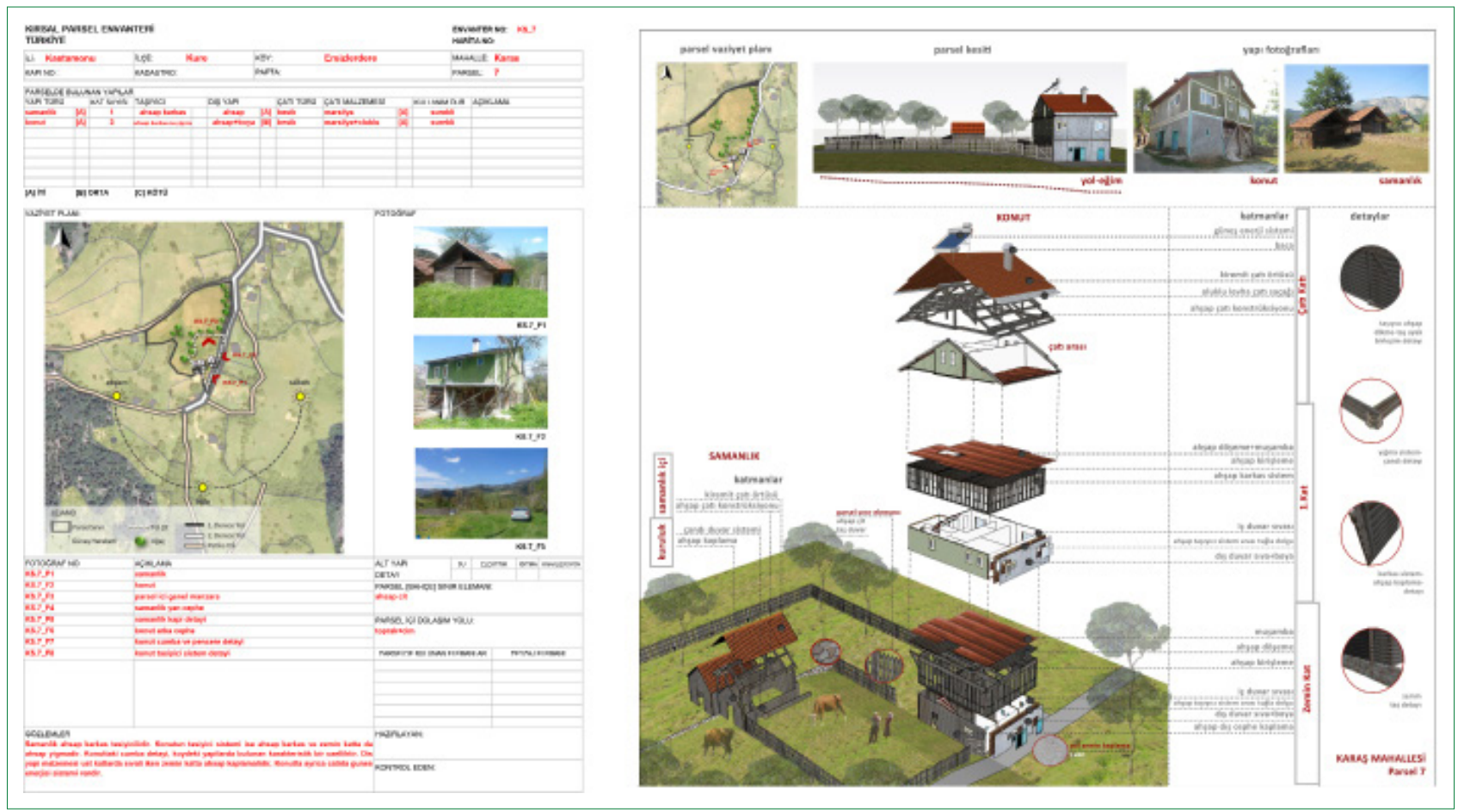

Şekil I0. Parsel föyü örneği (sol) ve parsel kullanımı/mimari ögelerin analizi (sağ). 


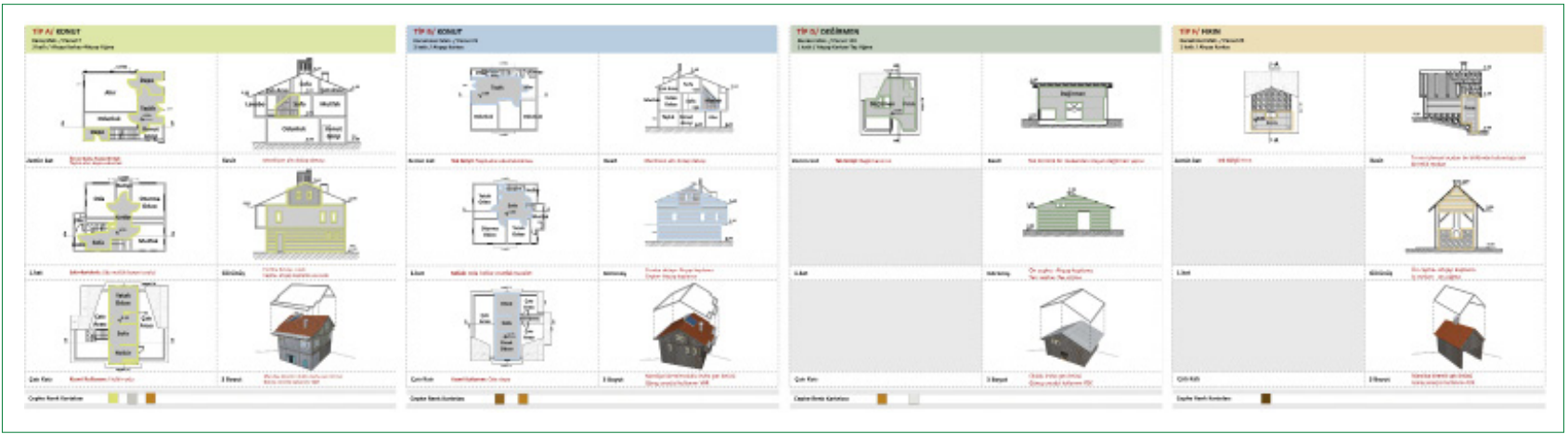

Şekil II. Yapı analizi.

denli korunabildiğine dair tespitler yapılmıştır. Ayrıca yapıların sahipleri ile bu yapılara ait eklemeler ve kullanım şekillerine dair bilgiler alınmış, sorunlar hakkında görüşülmüştür.

Çalışma kapsamında kullanılan yöntemlerden elde edilen bulgular ve köye dair temel bilgiler ışığında rehberin içeriği ve kurgusu belirlenmiştir. Temelde rehber üç ana bölümden oluşmaktadır. Bu bölümler Yerleşme Dokusu, Parsel Biçimlenişi ve Kırsal Mimari Karakteridir. Her bir bölüm alt başlıklarla değerlendirilmiş; sorunlar ve bu sorunlara çözümler üzerinden öneriler geliştirilmiştir (Şekil 12). Rehberde özellikle her tür kullanıcının rahatlıkla faydalanması amacıyla kısa ve net cümleler kullanılmış, resim ve teknik çizimlerle bu ifadeler desteklenmiştir.

Rehberin ilk bölümü olan "Yerleşim Dokusu” beş alt başlıkta ele alınmıştır (Şekil 13). Temelde yerleşimin içinde bulunduğu coğrafya ile bir bütün olduğundan hareketle köyün kimlik

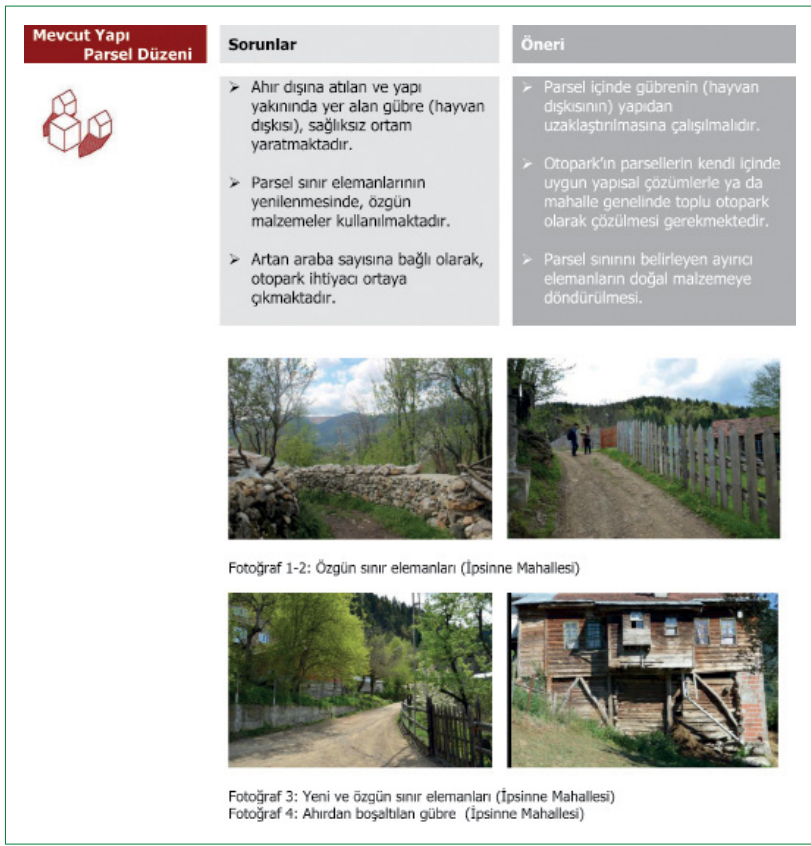

Şekil I 2. Rehberin kurgusu. özelliklerini ortaya koyan bu başlıklara dair sorunlar ve çözüm önerileri geliştirilmiştir. İlk olarak Topografi/Konum alt başlığında çalışma alanın içinde bulunduğu coğrafya içindeki konumu ve topografik özellikleri ele alınmıştır. Çalışma alanı içinde kanyon oluşumu köyün içinde bulunduğu peyzajın önemli kimlik özelliklerinden birini oluşturmaktadır. Bu kapsamda silueti bozan yapılaşmanın önlenmesi önerisi geliştirilmiştir. Buna ek olarak köylerin içinde bulunduğu arazinin engebeli yapısı nedeniyle mevcut köy siluetlerini bozacak yapılaşma ve istinat duvarı yapımından kaçınılması vurgulanmıştır. Ayrıca yeni yapıların vadi yamaç, vadi etek ve vadi hattı özelliklerini bozmadan arazi morfolojisine uygun biçimde yapılması önerilmiştir. Çalışma alanı içinde var olan derenin taşkın sınırları içinde yeni yapılaşmanın olmaması ve dere güzergâhı boyunca yapılan kanyon yürüyüşlerinde geliştirilebilecek yeni patika ve yolların arazi morfolojisine uygun bir biçimde bitki örtüsüne zarar vermeden konumlandırılması önerilmiştir.

Bir diğer alt başlık yerleşmelerin içinde bulunduğu Bakı ve Rakımlardır. Özellikle yeni yapılaşmada arazi bakısının dezavantajlarını azaltacak biçimde yapım ve teknikler kullanılması önerilmiştir. Ürün yetiştiriciliğinde, bahçe ve tarlaların konumunun bakı yönü dikkate alınarak belirlenmesi vurgulanmıştır.

Bitki ve Arazi örtüsü alt başlığında, arazinin mevcut bitki örtüsünü dikkate alarak yapılaşması önerilmiştir. Orman-yerleşim sınırlarının korunması, kır ve meraların kesinlikle yapılaşmaması, tarla orman sınırlarında yöreye özgü bitki türleri kullanılarak ormana geçişin sağlanması önerilmiştir. Ayrıca bahçe içinde kullanılacak bitki türlerinin yöreye özgü bitkilerden seçilmesi, egzotik bitki türlerinin kesinlikle kullanılmaması vurgulanmıştır.

Yerleşme Dokusu başlığındaki bir diğer alt başlık olan Ortak Kamusal Mekânlar köyün kamusal yaşamının geçtiği en önemli alanlardandır. Temelde mekânların fiziksel kalitesinin artırılarak köyün karakterine uygun biçimde gelişmesini sağlayacak tasarım ögeleri önerilmiştir. Köy yerleşim dokusundaki ortak alan ihtiyacından dolayı, köy meydanını daraltacak yeni yapılaşma olmaması, kalitenin artırılması için zemin ve cephelerde 


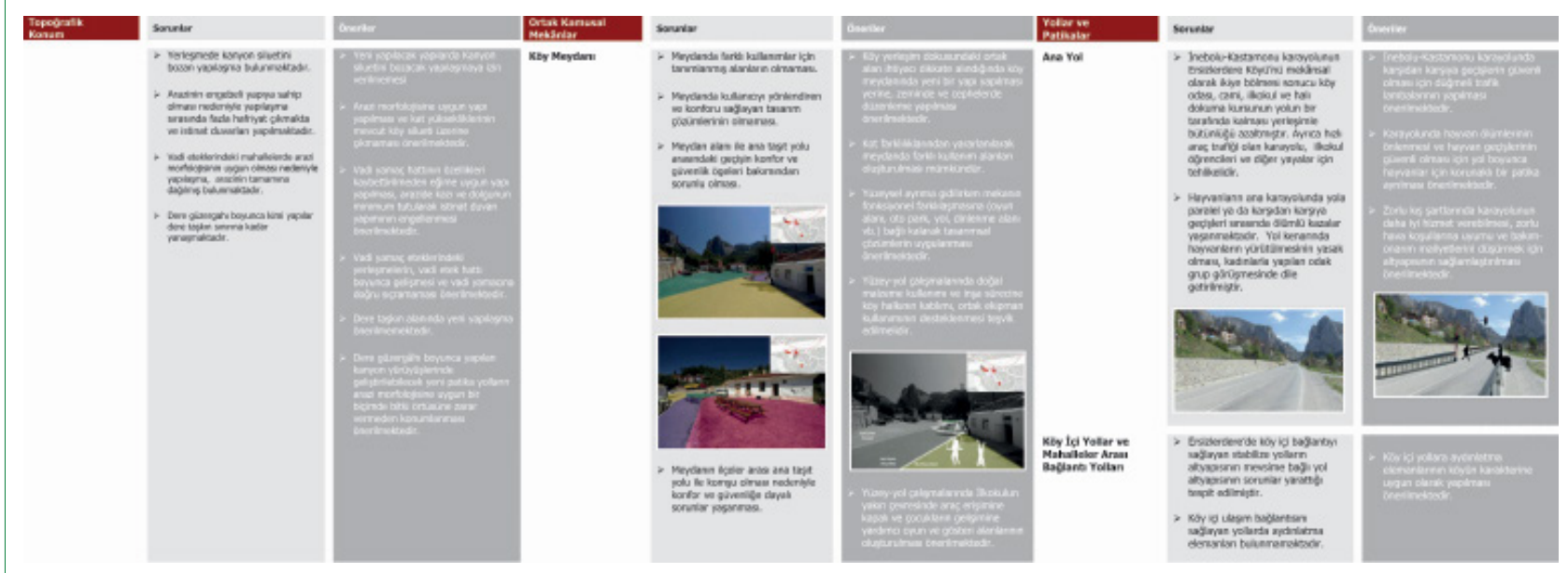

Şekil I3. Yerleşim Dokusuna ilişkin rehber önerileri.

düzenlemeler yapılması önerilmiştir. Meydandaki kot farklıklarından yararlanılarak farklı fonksiyonlar için alan açılmasının önemi vurgulanmış ve özellikle meydana ilçeler arası taşıt yolundan girilmesi sorununa dair öneriler geliştirilmiştir. Diğer bir ortak mekân olan harman yerine dair de aydınlatma, içme suyu ve kullanma suyu gibi alt yapıların sağlanmasıyla ilgili önerilerde bulunulmuştur.

"Yollar ve Patikalar" altbaşlığında yerleşme dokusunun ana strüktürünü oluşturan yollar ve patikalar için öneriler geliştirilmiştir. Özellikle İnebolu-Kastamonu kara yolunun çalışma alanı içinden geçmesinin köylüler için tehlike arz etmesinden dolayı, geçişlerin güvenli hale getirilmesi için sinyalizasyon önerisi geliştirilmiştir. Ayrıca kara yolunda hayvan ölümlerinin önlenmesi ve geçişlerin güvenli olması için hayvanlar için korunaklı alternatif bir yol boyu patika ayrılması önerilmiştir. Köy içi yollarda da gerekli yerlerde köyün karakterine uygun aydınlatma elemanlarının konumlandırılması belirtilmiştir. Köydeki önemli ulaşım ağlarından biri olan patikalar için yörenin iklim ve arazi karakterine ve yürüyüş için uygun malzemeler kullanılması önerilmiştir. Arazi morfolojisinden kaynaklanan engebeli yerlerde patikalarda basit çözümlerle basamak yapılması ve özellikle bu yapım sırasında arazinin mevcut örtüsüne mümkün olduğunca az zarar verilmesi önerilmiştir.

Rehberdeki ikinci bölüm “Parsel Biçimlenişi”dir (Şekil 14). Köy yerleşimlerinde köyün karakterinin oluşmasında ve yerleşim dokusunun belirlenmesinde önemli bir etkiye sahip olan

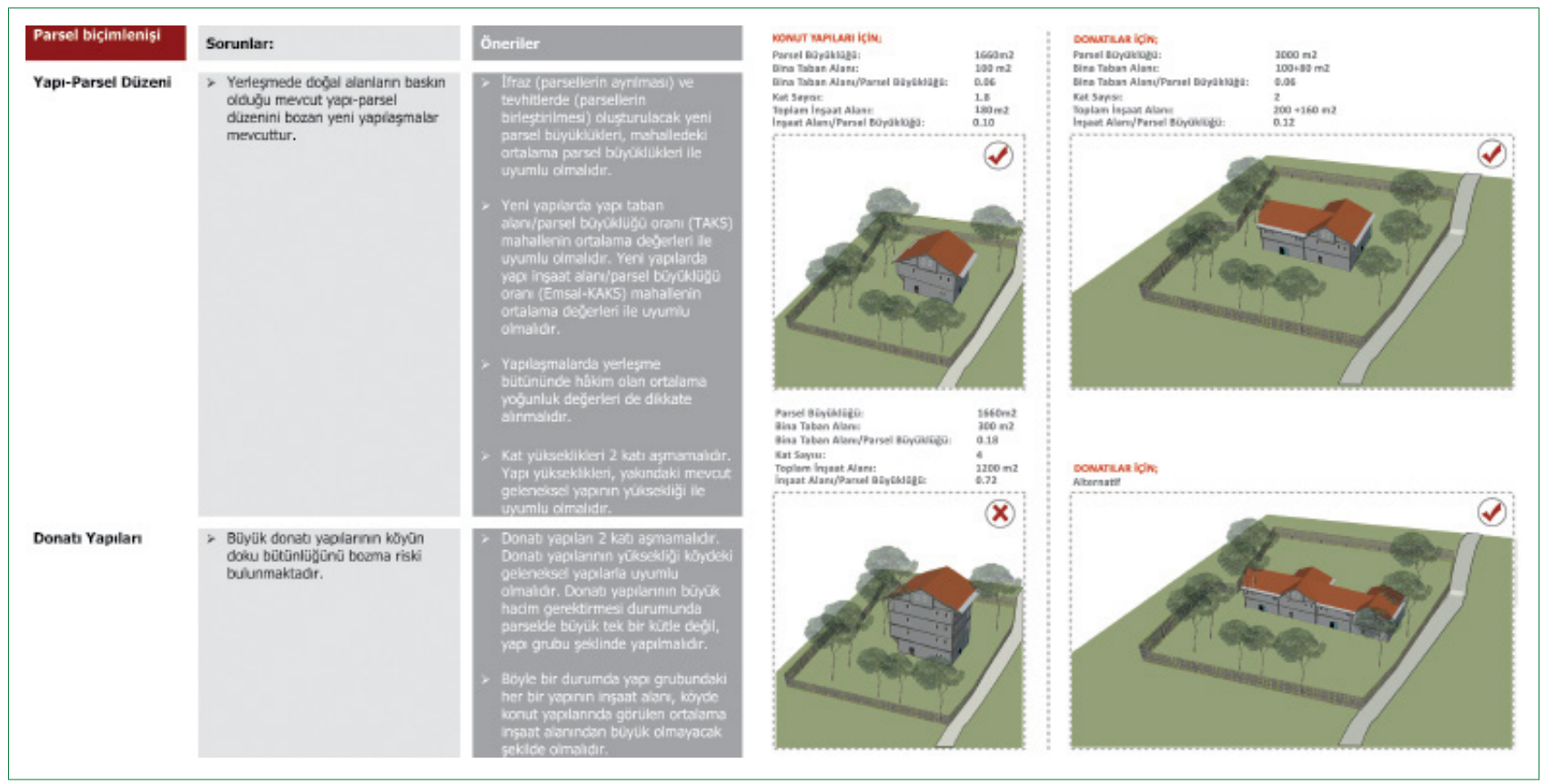

Şekil I4. Parsel biçimlenişine dair rehber önerileri. 
parsel biçimlenişine dair arazide ayrıntılı çalışmalaryapılmıştır. Temelde köyde mevcut parsel düzeninin korunması hedefiyle yeni oluşturulacak parsellerin köydeki parsel büyüklükleri ile uyumlu olması önerilmiştir. Aynı biçimde TAKS (emsal) değerlerinin, parselin bulunduğu mahallenin ortalamasında olması vurgulanmıştır. Buna ek olarak köyde kat adetinin 2'yi geçmemesi ve kat yüksekliklerinin komşu parseldeki geleneksel konutların kat yüksekliğine uyumlu biçimde yapılması önerilmiştir. Çalışma alanı içindeki donatı alanları ile ilgili olarak büyük hacim gerektiren yapılarda parsel içine tek büyük bir yapı yapılması yerine yapı grubu şeklinde tasarlanması önerilmiştir.

Rehberin son bölümünü oluşturan "Kırsal Mimari Karakter” başlığı altında hem mevcut yapılar hem de yeni yapılar için öneriler yapılmıştır. Bölümün alt başlıkları, Parsel Düzeni, Yasal Süreç ve Yapı Ustalığı, Bozulma Durumu ve Müdahaleler, Mekân Organizasyonu, Yapım sistemi, Yapı Malzemesi, Yeni Yapılar İçin Önerilerdir. Köyün iklim koşulları gereği ısınma ve yalıtım önerileri odak grup toplantılarında üzerinde durulan bir konu olmuştur. (Şekil I5). Rehberde ayrıca yapıyı oluşturan her öge için (taşıyıcı elemanlar, çatı, cephe vb.) onarım önerileri getirilmiştir. Konforu arttırıcı mutfak ve banyo ekleri önerilmiştir. Ayrıca ahşap köy evlerinin onarılabileceği, ısıtılabileceği, ve daha konforlu hale getirilebileceği vurgulanmıştır.

Rehberde yeni yapılacak yapıların sert iklim koşullarından en az etkilenecek şekilde doğru yönlenmesi ve iç mekân düzenlemesi için öneriler de yer almıştır. Yapıların mimari bakımdan köy ile uyumlu olması için kütle, yükseklik, çatı eğimi, cephede boşluklar vb. mimari detaylara ilişkin mevcudu referans alan öneriler tanımlanmıştır.

\section{Rehberden Sonra}

Rehberin basılması ve ilgili aktörlere iletilmesinden sonra da süreç devam etmiştir. MSGSÜ tarafindan rehberi temel alarak kırsal konut ve çok amaçlı sosyal tesis projeleri hazırlanmıştır. Oluşturulan proje modüler yapısıyla Ersizlerdere Köyü’nün birbirinden uzak, farklı doku özellikleri sergileyen ve farklı ihti- yaçları olan mahalleri için alternatif çözümler sunmuştur. 2017 yılının Mayıs ayında proje Kastamonu 7. Ahşap Fuar'ında sergilenmiştir. Fuara katılanların da ilgisini çeken proje, ilgili yöneticilerde de uygulama konusunda tetikleyici bir etki yaratmıştır. Bundan sonraki aşamada, üretilen projenin veya rehbere dayanarak üretilecek yeni projelerin Küre'nin ustalarıyla inşa edilebilmesi için usta eğitim programlarının uygulanması gerekmektedir. Çok amaçlı sosyal tesis, hem köy kadınları ile yapılan görüşmede talep edilen ortak mekân ihtiyacını karşılamış olacak, hem de yine görüşmelerde bir ihtiyaç olarak ortaya çıkan ürün tanıtım ve satış mekânı olarak da kullanılabilecektir.

Bundan sonra yerel yönetimin mekânsal düzenlemelerde rehberi dikkate alması önemli bir adım olacaktır. Köy halkının evlerin onarımında ve yeni ev yapımında rehberi kullanmasının teşvik edilmesi ve iyi örneklerin köyde yaygınlaşması ile rehber kullanışı bir araç olarak başarıya kavuşacaktır.

\section{Değerlendirme/Tartışma}

Ülkemiz için geliştirilecek bir köy tasarım rehberi programının hangi yaklaşımı benimseyeceği çok önemlidir. Ersizlerdere Köy Tasarım Rehberi çalışmasının temel yaklaşımı rehberin kırsal kalkınmanın bir parçası olarak ele alınmasıdır. Rehber Valilik, Bölge Kalkınma Ajansı ve Üniversite olmak üzere üç kurumun bölgedeki temel sorunlardan yola çıkarak bir ilçenin geleceğini tartışmak üzere halkı ve yerel/merkezi kurumları harekete geçirmesi ile başlayan bir çalışmanın parçasıdır. Bu bakımdan güçlü bir bağlamı olduğu görülmektedir. İkincisi rehberin kurgusu, bir yandan özgün doğal koşullar ve köy halkının ihtiyaçları ile biçimlenmiş, bir yandan da farklı uzmanlık alanlarının dünya deneyimlerini ülkemiz koşulları ile birleştiren birikimlerini yansıtmıştır. Çalışma yerele özgü olduğu kadar başka yerlerde de uygulanabilecek bir içeriğe sahiptir. Son olarak, çalışma bir sonuç ürün olarak değil bir sürecin başlangıcı olarak görülmektedir. Bu süreçte kurumlararası işbirliği ve köy halkının desteği çok önemlidir. Yani çalışma bir iş birliği süreci olarak kurgulanmıştır.
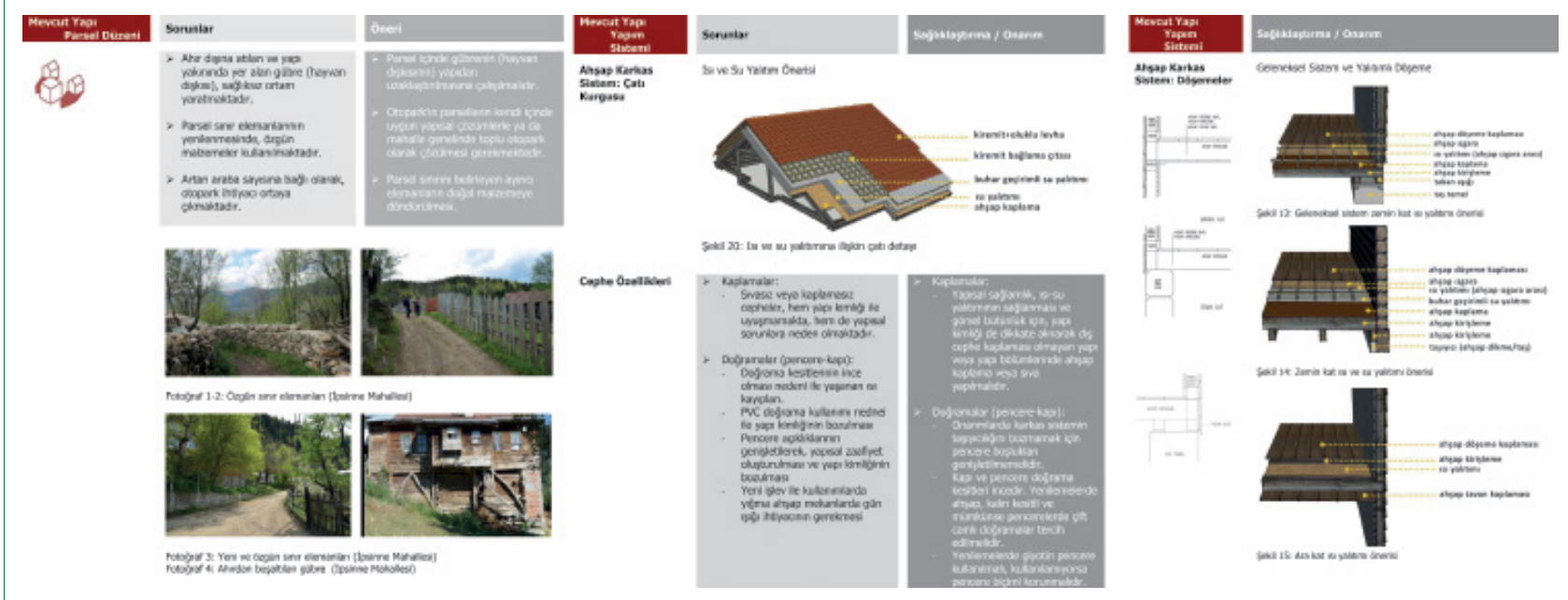

Şekil 15. Kırsal mimari karaktere ilişkin rehber önerileri. 
Ülkemiz için hazırlanacak bir köy tasarım rehberinde bu üç unsurun, yani bağlam, içerik ve işbirliği süreçlerinin birbiriyle tutarlı şekilde geliştirilmesi çok önemlidir. Aksi halde köy tasarım rehberi tek başına zayıf, çok da etkin olmayan bir doküman olarak kalabilir.

Kuşkusuz ülkemizde bazı olumsuzluklar bu koşulların sağlanmasını zorlaştırmaktadır. Köylerin başka sorunlarının daha öncelikli olması, kırsal alanda katılım tecrübesinin eksikliği, yerel yönetimlerin sınırlı imkânları gibi birçok kısıtlayıcı etken söz konusudur. Ancak ülkemiz köylerinin çeşitliliği, özgünlüğü henüz yok olmadan doğru bir yaklaşımla, doğru yer seçimleriyle ve uygulanabilir yöntemlerle kırsal yerleşimlerin korunması ve iyileştirilmesi için bir araç olarak köy tasarım rehberlerini hayata geçirmek gerekmektedir.

Bir köy tasarım rehberi hazırlanırken şu konulara dikkat edilmelidir;

Bağlam açısından öneriler: Mevzuatta da belirtildiği gibi her köyde bir rehber yapılması zorunlu değildir. Köyde kırsal karakterinin güçlü olduğu, turizm ya da sanayi gibi gelişme baskısının mekânsal olarak gözlemlendiği, köy halkının birlikte hareket etme tecrübesine ve köye dair olumlu bir yaklaşıma sahip olduğu, yerel yönetimin istekli olduğu durumlarda köy tasarım rehberi için uygun koşullar var demektir.

Köyde çok daha acil sorunların olması durumunda (temel altyapı eksikliği, afet durumu vb.), köy tasarım rehberinin öne çıkarılması, rehbere olan desteği zayıflatacaktır. Acil sorunun çözümü için başka uygun araçlar geliştirilmelidir.

Rehberin tek başına bir araç olarak kalmaması ve ölçekler arası ilişkilerinin kurulmuş olması başarısı için çok önemlidir. Rehberin ulusal düzeyde daha kapsamlı sosyal ve ekonomik kalkınma programları ile ilişkileri kurulmalıdır. Bu programlardaki önceliklerle uyumlu olmaları halinde uygulama aşamasında diğer projelerle birlikte hareket edilebilir ve desteklere ulaşma imkânları yaratılabilir.

Rehberin üst ölçekli mekânsal stratejilerle ilişkisinin kurulması gerekir. Rehberler bu stratejilerin mekânda karşılı̆̆ını bulması için bir araç olarak düşünülmelidir. Ulusal ölçekte tasarım ilkeleri ile ilgili çerçeve dokümanlar oluşturulması durumunda köy tasarım rehberlerine de referans olacak bir içerik oluşturulmalıdır.

Orta ölçekte planlama sistemine nasıl entegre olacağının belirlenmiş olması gerekir. Yerleşme ya da çevresi için yapılmış bir mekânsal plan varsa, rehberin plan ile nasıl bütünleşeceği belirlenmiş olmalıdır (plan eki, plan notu vb.). Rehberin içeriği; ilgili plandaki kararlarla uyum sağlayacak şekilde olmalıdır. Bazen planlarda eksik kalmış konularda rehberler planı yönlendirici de olabilir.
En önemlisi de köy tasarım rehberleriyle ilgili mevzuatın ve kurumsal sorumlulukların tanımlanmasıdır.

İçerik açısından öneriler: Köy tasarım rehberlerinin içeriği mevzuatta yer almadan önce pilot köyler seçilerek farklı yaklaşımlar denenmeli, hangi konuların yerele özgü olduğu, hangi konuların her yerde uygulanabileceği görülmelidir. İçerikler pilot çalışmalar değerlendirildikten sonra mevzuata yansımalıdır.

Köy tasarım rehberinde bölgedeki temel kırsal kalkınma sorunlarından hareketle önceliklerin belirlenmesi önemlidir. Yerelde üretim, istihdam, çevre, kültürel boyutlardan biri ya da birkaçı öne çıkabilir, rehberdeki önerilerin bu konulara hassas olması beklenir.

Köy tasarım rehberleri farklılıklar üzerinden geliştirmelidir. Yerleşmeye has özellikler köy halkı tarafından daha iyi bilinir. Bu nedenle araştırmalarda köy halkının yerel bilgisi öne çıkarılmalıdır.

Rehber yerleşim ölçeğinden yapı ölçeğine kadar öneriler içermekle birlikte, her rehberde ağırlıklar farklı olabilir. Örneğin hızlı gelişme baskısı olduğu durumda yerleşme ölçeğine ağırılk verilirken, tarihi yapıların olduğu bir yerde mimari ölçek ağırlık kazanabilir.

Rehberler sadece köyün yerleşik alanı ile değil, yakın çevresi ile de ilgilenmelidir.

İşbirliği ve süreç açısından öneriler: Köy tasarım rehberi, yerel/bölgesel kurumların işbirliği ve köy halkının katılımı ile geliştirildiği takdirde kalıcı ve başarılı olacaktır. Hatta bu işbirliği henüz zayıf ise, yerel yönetimlerin köy halkı ve yerel/ bölgesel diğer kurumlarla işbirliği eğilimleri köy tasarım rehberleri üzerinden daha hızlı geliştirilebilir; işbirliğinin daha somut eylemlerle güçlenmesi, etkin ve kalıcı olması sağlanabilir.

Rehber bittiğinde süreç henüz yeni başlamıştır. Devam eden süreçte rehberin kullanılması, gerektiğinde yenilenmesi ve bu süreçte kurumların ve halkın ilgisinin devam etmesi rehberin başarılı sayılması açısından önemlidir.

Köy tasarım rehberlerinin ülkemiz koşullarına uyarlanmış, kullanılabilir araçlar olarak geliştirilmesi için öncelikle iyi örnekler ve tecrübeler üzerinden yola çıkılması gerekir. Küre Ersizlerdere Köy Tasarım Rehberi, ülkemizin sosyoekonomik gelişmişlik açısından üst sıralarda yer almayan bir bölgesindeki bir köy için yerele özgü kalkınma çözümlerinin en zor şartlarda dahi gerçekleştirebileceğini, mekânsal 'tasarım' ilke ve kararlarının geliştirilebileceğini göstermiştir.

Bu çalışmanın ortaya çıkmasında etkili olan süreçler her kadar tekrarlanabilir olmasa da rehberin geliştirilmesinde kurumsal sahiplenme, akademik katkı ve yerel katılımın önemli olduğu, rehberin içeriğinin ise yerele özgü biçimlendiği görülmektedir. Ülkemizde ilk köy tasarım rehberi örneği olan Ersizlerdere Köy Tasarım Rehberinin kendi koşullarımıza uygun bir uygulama pratiğinin oluşmasında katkısı olması beklenmektedir. 


\section{KAYNAKLAR}

Arnstein, S. R. (1969). A Ladder Of Citizen Participation. Journal of the American Institute of Planners, 35(4), 216-224.

Atkins, W. S. (1998) Monitoring Countryside Design Summaries and Village Design Statements, Unpublished report to the Countryside Commission, July.

Aysu, A.(2013). Küresel Kapitalizme Koşut Olarak Türkiye Tarımında Değişim, Dönüşüm, Kırsal Planlama Üzerine Tartışmalar. MSGSÜ.

Clifford, S. ve King, A. (1993). Local distinctiveness: Losing your place. Londra: Common Ground, Gold Hill House.

Cork County Council. (2003). Cork rural design guide: Building a new house in the countryside. Ireland.

Countryside Agency (2002). Village design statements-their Influence on new development. Cheltenham: Countryside Agency.

Çelik, Z. (2005). Planlı Dönemde Türkiyedeki Kırsal Kalkınma Politika ve Uygulamaları Üzerine Bir Değerlendirme, Planlama Dergisi, 2005 (2), 61-71.

Çetin, T. (1999). Modern Türkiye Yaratma Projesinin Orijinal Bir Boyutu: Örnek Köyler, içinde O. Baydar (ed.). 75 Yılda Köylerden Şehirlere, Tarih Vakfi, İstanbul, 231-240.

Eminağaoğlu, Zehra (2004). Kırsal Yerleşmelerde Dış Mekân Organizasyonu İlgili Politikalar ve Değerlendirmeler, Yayınlanmamış Doktora Tezi, Karadeniz Teknik Üniversitesi, Fen Bilimleri Enstitüsü.

Gallent, N., Morphet, J. ve Tewdyr-Jones, M. (2009). Parish Plans and the spatial planning approach in England Town Planning Review, 79(1),1-29.

Gıda Tarım ve Hayvancilık Bakanlığı. (2015). Ulusal Kırsal Kalkinma Stratejisi 2014-2020.

Güler, Z., Çırakoğlu, D., Tokmak, M. (2014). Türkiye'de Kırsal Kalkınma Modeli Olarak Köy-Kent Uygulamaları: Bolu Mudurnu İlçesi Taşkesti Örneği, Nevşehir Hacı Bektaş Veli Üniversitesi Sosyal Bilimler Enstitüsü Dergisi 4(2014), 155-167.

Hampshire County Council. (2009). Yateley Village Design Framework, Supplementary Planning Document. Hasluck, W.F. 1910. Cyzicus, Cambridge, England.

Harvey, D.(2013). Asi Şehirler, Ayșe Deniz Temiz (çev.), Metis Yayınları, İstanbul.

Hughes, C., (2006). Do village design statements make a difference? Town and Country Planning, 27(4),119-121.

İbret, Ü. (2007). Küre, Bakır Diyarının Coğrafyası, Aktif yayınları, Ankara.

Kayıkçı, S. (2005). Cumhuriyetin Kuruluşundan Günümüze Kadar Köye ve Köylüye Yönelik Olarak İzlenen Politikalar, Türk İdare Dergisi, (448), 69-99.

Kazancı, Ş., Aydınlı, G., Şimşek, C. (eds.) (2016). Geleceğe Küresel Bakış, Kırsal Kalkınmada Yerel Stratejiler Kitabı-2, Kuzey Anadolu Kalkınma Ajansı Yayını, Kastamonu.

Kilkenny County Council. (2009). Kilkenny Rural Design Guide, İreland.

Koç, B. ve Gül, A. (2006). Türkiye'de Bir Kırsal Kalkınma Modeli Olarak Köykentler ve Köykentlerde Tarımsal İşletmelerin Sosyal ve Ekonomik Analizi, Ankara: Tarım ve Köy İşleri Bakanlığı.

Melton Borough Council. (2007). Barkestone Village Design Statement.

McKinsey Global Institute. (2011). Urban world: Mapping the economic power of cities.

Owen, S., Bishop, J., O'keeffe, B. (2011). Lost in translation? Some issues encountered in transferring village design statements from England to Ireland. Journal of Urban Design, 16, 3, 405-424.

Owen, S. (1998). The role of village design statements in fostering a locally responsive approach to village planning and design in the UK, Journal of Urban Design, 3(3), 199-220.

Owen, S. (1999). Village design statements: Some aspects of the evolution of a planning tool in the UK, Town Planning Review, 70(1), 41-59.

Owen, S. (2002). Locality and community: Towards a vehicle for communitybased decision making in rural localities in England. Town Planning Review, 73, 1-21.

Owen, S.,Bishop, J., Moseley, M., Boase, R.,Coffey, F. (2008). Enhancing Lo- cal Distinctiveness: Evaluation of Village Design Statements (VDSs) in Ireland (2000 to date) Final Report to the Heritage Council, December 2008.

Rutland County Council. (2002). Langham Village Design Statement (VDS); England.

Saunders, P. (2013). Sosyal Teori, Kentsel Sosyoloji, Songül Doğru Getir (çev.), İdeal Kültür Yay.

Türkoğlu, P.(1999). Köy Enstitülerinde Köyden Alma-Köye Gönderme Politikası, içinde O. Baydar (ed.). 75 Yılda Köylerden Şehirlere, Tarih Vakfi, İstanbul, 220-224.

Quality Parish Council. (2014). Crowhurst Village Action Plan, 2014-2019.

Ünsal, H. T. (2012), "Effective Use of Design for Competitiveness and Brand Recognition", (Eds.) Bayrakci O., Biyiklioglu S., Gulen E. \& Ozyurt M., Mass Customization Researches and Design Studies on Consumer Electronics Design, pp. 74-77, Mimar Sinan Fine Arts University Publications, Istanbul.

Yücel, S.D., Kazancı, Ş. (eds.) 2014. Geleceğe Küresel Bakış, Kırsal Kalkınmada Yerel Stratejiler Kitabı, Kuzey Anadolu Kalkınma Ajansı Yayını, Kastamonu. 